\title{
UMA CONSTELAÇÃO DE RELAÇÕES ANTICAPITALISTAS NO SUL DO BRASIL: REDES POLÍTICAS E SOCIABILIDADES EMERGENTES LIDAS DESDE UMA ANTROPOLOGIA ANARQUISTA
}

\section{Daniel Francisco de Bem ${ }^{1}$}

\begin{abstract}
Resumo: Este esforço textual pretende analisar a sociabilidade de alguns atores sociais com os quais, e a partir dos quais, este investigador circulou em uma rede de pessoas, espaços, discursos e práticas identificadas como libertárias, autônomas, anarquistas. A constelação desses atores sociais: em suas pautas; em suas metodologias de propaganda e de ação, seja em âmbito privado ou público, na finalização e finalidade de suas projeções e seus projetos, foi estabelecida a partir de dois critérios. Primeiramente, eu conheci esses atores sociais, militei com esses indivíduos, coletivos e movimentos, e isso se torna um critério para essa análise. Em segundo lugar, entendo que uma segunda tessitura dessa rede, dessa constelação de atores sociais, se dá justamente por um tipo de dado, um tipo de informação, que se repete e se adensa nas ações e discursos de todos esses atores, qual seja, a busca de vivências libertária e autônomas para além da mera identificação. A referida constelação de atores sociais que tentarei aqui reproduzir analiticamente situa-se temporalmente a partir dos anos 2000 até a atualidade e espacialmente a partir do estado do Rio Grande do Sul.
\end{abstract}

Palavras-chave: Redes Políticas. Sociabilidades Emergentes. Anarquismo.

\section{INTRODUÇÃO²}

Pelo senso comum brasileiro contemporâneo, o espectro de identidades políticas à esquerda (para continuar usando o jargão clássico) termina naqueles auto ou heteroidentificados como comunistas. Por incontáveis anos o termo anarquista inexistiu como uma possibilidade política no horizonte imaginativo

1 Doutor em Antropologia pela UFRGS. Professor do Programa de Pós-Graduação Interdisciplinar em Ciências Humanas - UFFS e investigador do Grupo de Pesquisas Anticapitalismos e Sociabilidades Emergentes (GPASE). Email: danielfdebem@gmail.com

2 Este texto é uma versão inédita da comunicação de mesmo nome apresentada no Simpósio de Pesquisas Pós-Graduadas "Anticapitalismo, Democracia Radical e Sociabilidades Emergentes" ocorrido durante o $40^{\circ}$ Encontro Anual da ANPOCS. 
do brasileiro médio. A grosso modo, depois do protagonismo anarquista nas greves dos anos 1910 e durante a década de 1920, o anarquismo praticamente silenciou no Brasil seja pela aposta de convergir com os comunistas na formação do PCB em 1922, seja pela pelo aumento flagrante da perseguição de seus militante, sobretudo no governo de Artur Bernardes (1922-1926). Na década posterior, o flerte fascista do governo Vargas e a organização de um sindicalismo estatal soterrou as possibilidades de uma militância pública dos ideias anarquistas de maior vulto, salvo valentes exceções como o Centro de Estudos Anarquistas (idealizado por José Oiticica) e, talvez, a simpatia de intelectuais como Maurício Tragtenberg.

Só após a abertura política do final dos anos 1970 é que a o anarquismo revitalizou-se como discurso público com ênfase em: uma agitação cultural, advinda da identificação com a cena musical juvenil punk e com a contracultura; em uma vertente editorial-acadêmica, através da reedição ou publicação de literatura anarquista e da formação de círculos de estudo; e na militância anarcossindicalista, sobretudo em organizações como CCS-SP (Centro de Cultura Social de São Paulo) e a COB (Confederação Operária Brasileira).

Obviamente que essas expressões do movimento anarquista no Brasil a partir da década de 1980 não formaram vertentes excludentes, nem se capilarizaram, muito menos se massificaram como os movimentos sociais ligados às ideologias marxistas (MST) e à esquerda eleitoral (PT). Só a partir dos meados dos anos 1990 com a visibilidade do movimento anticapitalista em âmbito mundial é que as concepções anarquistas voltam a ter algum destaque no horizonte político brasileiro. Primeiro de forma bastante sutil, mas com o adentrar do novo século, de forma cada vez mais presente em movimentos de rua, como as várias manifestações relativas a carestia do transporte público, que tiveram seu ápice em 2013; ou as manifestações contra a realização de Megaeventos no país, como a Copa do Mundo e em menor escala as Olimpíadas; ou as cada vez mais presentes marchas: "das Vadias" (de cunho feminista), "da Maconha" (Antiproibicionista), e intervenções ou ocupações urbanas como táticas correntes dentro dos mais diversos temas e para os mais diversos propósitos.

Não quero com isso dizer que todos esses eventos e ações eram em sua organização ou em seus conteúdos ou por seus participantes anarquistas. Mas muitos dos elementos disparadores e de como se desdobraram contextualmente esses eventos tiveram muita influência (ou adesão) de agentes, táticas e ideias 
anarquistas. Seja nas formas como os manifestantes acolheram e dinamizaram as propostas e somaram-se aos eventos; seja na a performatização dessas ações, muitas delas quase ou completamente anônimas, autogeridas, com recursos bastante precários, sem lideranças identificadas, sem vínculos partidários fortes, com discursos de denúncia de agressões ou de reivindicação de direitos, mas também, muito pautadas pelo empoderamento pessoal e imediato e pela desobediência civil, no melhor estilo "Se não eu, quem? Se não agora, quando?".

Mesmo assim, depois de décadas de ostracismo no horizonte político da maioria da população, muito por conta da perseguição das próprias correntes marxistas - "competidoras" e "predadoras" dentro do campo das esquerdas, sedentas da hegemonia ideológica - e dos demais grupos políticos, mais à direita, defensores da lógica estatista e eleitoral, é difícil que o anarquismo tenha alguma ressonância fidedigna de seus pressupostos dentro da sociedade mais ampla. Se os militantes anarquistas apoiam por razões táticas ou políticas as ações do tipo black bloc são, juntamente com os seus usuários, tachados de vândalos, delinquentes, ou são identificados como alienados políticos, por não aceitarem o atual jogo eleitoral, ou, pior, são enquadrados como mais um grupo em busca de visibilidade para fins eleitorais.

Mas o anarquismo não é só isso, não está fundado apenas na recusa do Estado e na crítica ao Capital. Para além da negação, seu horizonte é o anúncio, da experimentação de construções coletivas que não sacrifiquem os indivíduos e a liberdade de individualidades não somarmo-nos ao que não nos interessa, estando conscientes do que ganhamos e perdemos com isso. Solidariedade, autonomia e autogestão. Os anarquistas, das mais diversas linhagens e correntes de pensamento e ação política, concordam com esse horizonte, almejando construir imediatamente o que for possível, fugindo do etapismo, da tomada do poder estatal e da imposição de sua ideologia desde os aparelhos ideológicos do mesmo. O problema, se é que isso é um problema, é que apesar de concordarmos nos objetivos e nas premissas, nos diferenciamos muito nas táticas, nos métodos e nas perspectivas de por onde segue nossa ação. Muitos de nós defendem a organização e a militância efetiva em vários segmentos da sociedade envolvente, como por exemplo: os plataformistas, especifistas, sintetistas; alguns estão organizados com mais foco na organização dos trabalhadores pelos seus locais de trabalho e seu papel como produtores, na mais clássica organização anarcossindicalista; outros trabalham em uma perspectiva mais difusa, de agitação cultural anarquista em diferentes frentes (editorial, acadêmica, musical, em diversos empreendimentos "faça você 
mesmo com baixos recursos" etc.); há também grupos de afinidade, de pessoas bastante próximas, com baixa organização e pequeno número de membros, que realizam ações específicas, ou têm um interesse por temas variados, mas sempre com uma orientação autonomista de juntar subsídios, técnicas e contatos para fortalecer iniciativas de caráter libertário e autônomo.

Esse é um pouco da herança e do panorama conjuntural do anarquismo, ou melhor, dos anarquismos que conheci a partir da virada do século XX para o século XXI em Porto Alegre, Rio Grande do Sul, Brasil. Se evoco a minha história pessoal para poder descrever um pouco mais daquilo que conheço desse movimento, é porque foi em experiência direta que conheci e participei de marcos conjunturais e eventos que configuram-se no processo de identificação anarquista, ou ao menos, libertária ou autonomista, de toda uma geração.

Para finalizar essa introdução, é necessário declarar alguns avisos estilísticos e metodológicos. No desenvolvimento do argumento centrarei minha atenção em certos eventos ou processos que considero focais, mas não me preocuparei em tecer descrições e reflexões pormenorizadas da constelação de elementos políticos e social ao redor do tema focal, tanto porque o espaço, e a finalidade, dessa escritura não os permitem, quanto por que a minha memória não é capaz de recuperar muitos desses elementos, alguns pelo tempo decorrido e outros porque a minha percepção sobre vários desses fenômenos era muito estreita.

Outra questão importante é que, excluindo organizações públicas em atividades públicas, eu alterarei na narrativa nomes de pessoas, grupos e organizações, com o objetivo de proteger suas identidades e seus interesses. Tem sido muito difícil para mim terminar esse texto, posto que se por um lado acredito na importância de disputarmos as narrativas sobre nossa época, nosso pensamento, nossa orientação política, para que o anarquismo não continue marginal, até para si mesmo; por outro lado, sei que sempre existem esforços estatais e de grupos reacionários que podem acabar aprendendo e apreendendo alguma coisa do anarquismo, para ser usada contra ele mesmo, e isso também pode ocorrer através desse tipo de texto, de caráter público e acadêmico, não sendo voltado apenas a militantes.

Longe tanto de teorias da conspiração quanto do realismo fantástico, vimos, em 2014, Bakunin ser citado como suspeito no inquérito da Polícia Civil do Rio de Janeiro sobre as manifestações de rua iniciadas em $2013^{3}$ e, mais

3 Fonte: Revista Fórum, edição de 28 de julho de 2014 , disponível em: 
recentemente, em setembro de 2016, foi exposto como infiltrado nas manifestações o capitão da Inteligência Militar Willian Pina Botelho ${ }^{4}$. Tais situações comprovam que, talvez mesmo não entendendo nada os aparatos de repressão estão fazendo o seu tema de casa e estudando os grupos de ação e interesse político mais a esquerda, o que, em tempos de flerte da democracia eleitoral com um pensamento mais conservador e de tendência fascista, pode colocar todos nós, militantes e acadêmicos interessados e simpatizantes, como alvos em potencial.

Mas não calarei a minha voz e a minha memória por causa do medo. É necessário disputar a narrativa, como escrevi antes, ou como escreveu Eduardo Galeano, em "Desmemória/4", de o Livro dos Abraços, reproduzindo um cartaz com um provérbio africano, que ele encontrara em uma loja de Chicago: "Até que os leões tenham seus próprios historiadores, as histórias de caçadas continuarão glorificando o caçador" (2005, p. 63-64).

\section{OS ANOS DE FORMAÇÃO}

Os diretórios acadêmicos dos cursos de Ciências Sociais, História e Letras, no Campus do Vale da UFRGS, têm nomes "engraçadinhos": CECS, CHIST e CEL, herança dos alunos que passaram por esses cursos na década de 1980. Logo que cheguei no curso de Ciências Sociais, em 1999, com 18 anos, me impressionei com as reuniões do CECS, rodas de conversa semanais aonde os veteranos discutiam as questões do curso e a conjuntura nacional, no derradeiro governo de FHC. Na esfera estadual e municipal, eram os últimos anos da hegemonia petista no Rio Grande do Sul.

Nessas reuniões, nas quais os participantes variavam entre 6 e 20, a maioria dos estudantes engajados nas discussões eram vinculados a partidos como o PT, o PCdoB, o PSTU, faziam parte das suas juventudes, alguns eram CCs (Cargos Comissionados) em gabinetes de vereadores e deputados ou estagiários em alguma secretaria de governo. Era muito ambígua a forma como permitiam a manifestação dos calouros em relação aos temas pautados, um misto de incentivo e desprezo aos neófitos da/na política, sendo que poucas vezes nossas ideias eram levadas a sério. Destoavam um pouco desse perfil dois militantes de

http://www.revistaforum.com.br/2014/07/28/filosofo-russo-ja-morto-e-citado-como-suspeito-eminquerito-rio-de-janeiro/, acessado em 15 de setembro de 2016.

4 Fonte: Jornal El Pais - Brasil, edição online do dia 09 de setembro de 2016, disponível em: http://brasil.elpais.com/brasil/2016/09/09/politica/1473452777_631937.html, acessado em 15 de setembro de 2016. 
um coletivo chamado Tendências Autônomas. Foram eles os primeiros anarquistas que eu conheci. Havia também um outro veterano, que sempre agitava alguma ação, mas não se declarava anarquista, mas libertário; de comportamento tempestuoso e maníaco, muitos dos seus posicionamentos eram também desconsiderados, mas ele sempre estava "causando".

O fato é que com o passar dos semestres, não só eu, mas vários colegas perceberam que as figuras do diretório eram sempre as mesmas, ora se revezando na gestão do CECS, ora formando coligações esdrúxulas para se manterem à frente do mesmo. As comissões compostas com pessoas externas a esse grupo, também, sempre sendo preteridas.

\subsection{O CECS LIVRE}

Nesse contexto, surgiu, a partir do primeiro semestre de 2000, na convergência de várias propostas alternativas, a busca por realizar uma assembleia geral dos estudantes do curso para pensarmos se realmente precisávamos continuar no regime representativo, com eleições e cargos definidos para pessoas definidas ou se poderíamos experimentar um diretório organizado através de comissões onde pudessem participar todos aqueles estudantes que assim quisessem. Passamos grande parte do semestre discutindo os "prós" e os "contras" do modelo representativo e da autogestão. Quanto a metodologia de consulta, tivemos várias contendas quanto ao quórum mínimo que pudesse ser considerado como expressivo da vontade geral dos alunos do curso. A questão é que, como sempre, a maioria dos alunos não se importava com o diretório acadêmico e pra eles era indiferente como seria sua organização.

Por fim, em duas assembleias, beirando o quórum mínimo estipulado, acabou ganhando por uma diferença de três votos, a constituição do CECS no formato autogestionário de comissões, por tempo indeterminado, a experiência ficou conhecida como "CECS LIVRE". O período subsequente foi bastante exitoso. Embora, um número reduzido de estudantes tenha participado do cotidiano de nosso diretório, houve uma renovação nas figuras que traziam as pautas. Também incrementou-se um sincero engajamento que, somado com uma certa desconfiança dos partidos, elevou a autoestima e o empoderamento político dos indivíduos que ali realizavam a política estudantil.

Alguém pode falar que o grosso de nossa política era a realização de festas, mas não é verdade, realizamos muitas discussões sobre os assuntos que ocupavam nossa reflexão como estudantes de Ciências Sociais, usuários do 
Campus do Vale e como cidadãos. Discutíamos: a ainda remota, possibilidade da obrigatoriedade da sociologia no currículo escolar; a situação das comunidades indígenas Guaranis e Kaingangs localizadas em Porto Alegre, das quais alguns membros demandavam livre acesso ao perímetro do nosso Campus para a extração de matéria-prima para a confecção de artesanato; a questão do preço dos RUs e o uso e a cedência de espaços destinados aos estudantes universitários para empreendimentos privados, entre tantas outras questões. Sendo que no processo de discussão, sempre horizontal, espontaneamente íamos nos acercando de estudantes de outros cursos, sobretudo os de vizinhança geográfica ou epistemológica, como os alunos de História, Letras, Geografia, Filosofia, Biologia.

Nessa conjuntura, duas ações que realizamos em grupo com alunos de outros cursos foram paradigmáticas para marcar com mais profundidade essa busca pelos ideais anarquistas, ou pelo menos libertários e coletivistas, em toda uma geração de estudantes dos cursos antes citados. A quebra do relógio dos 500 anos foi a primeira e a segunda foi a retomada do Centro de Vivência dos Estudantes, "CV" para os íntimos.

Desde 1998 a Rede Globo estava promocionando uma contagem regressiva para os 500 anos da "Descoberta do Brasil". Com a ajuda do empresariado e do governo FHC inaugurou em diversas capitais relógios comemorativos, que dividiram a opinião pública por conta do duvidoso senso estético do projeto e do desserviço à reflexão histórica. Em âmbito nacional foi organizado o movimento "Brasil outros 500" que realizou vários atos públicos aos quais afluíram militantes dos mais variados movimentos sociais. E é claro que em Porto Alegre também ocorreram uma série de atos e manifestações.

Com a aproximação do 22 de abril de 2000, todo esse clima de agitação político-cultural foi se espraiando. Para a madrugada do dia foi imaginada uma vigília em frente ao Relógio de Porto Alegre, então localizado no Parque Harmonia, próximo ao prédio do antigo Gasômetro e à orla do rio Guaíba. Alguns alunos das Ciências Sociais, pensaram em chamar alguns amigos indígenas e realizar uma dança de guerra marcando a posição contrária à ideia de "descoberta do Brasil", lembrando da população nativa que vem sofrendo uma guerra genocida desde a invasão e do não reconhecimento de sua soberania e autonomia. Naquele momento, em uma rede de contatos curta e com dificuldades financeiras e de transporte, esse grupo não conseguiu trazer muitos indígenas, então se pintaram eles mesmos e encenaram a sua dança de guerra. Já na manhã do dia 22 , um daqueles veteranos anarquistas do nosso 
curso, estava indo para a manifestação com a mochila repleta de pregos, isopor e com uma garrafa pet vazia, foi parado pela polícia e foi conduzido até a delegacia para dar explicações sobre a suposta maquete que ele estava indo construir na casa de um amigo. A sorte dele (além de ser branco) é que não tinha conseguido comprar a gasolina que queria acondicionar na garrafa pet, se não talvez estivesse em uma situação parecida com a de Rafael Braga, preso por porte de "Pinho Sol" nas manifestações de 2013.

Durante a tarde do dia 22, a concentração de pessoas ao redor do relógio foi aumentando e a coragem e os ânimos também tiveram uma escalada. Manifestantes começaram a jogar pedras no relógio e a baterem nele com paus. Um estudante, mais por graça que por outro motivo, resolveu escalar o relógio e se sentar em seu alto. A multidão demandou que ele fizesse força com o pé sobre o mecanismo dos ponteiros, e aí se seguiu a quebra do relógio e seu incêndio. Teve algum tumulto com a polícia, algumas pessoas foram indiciadas, entre elas o estudante que subiu no relógio. Esses elementos não importam tanto agora e confesso consternado que eu estava hospitalizado e só me inteirei dos acontecimentos pela cobertura jornalística e depois da minha alta pela "rede de notícias" entre os estudantes do Campus do Vale. Aliás por anos ficamos contando histórias sobre a quebra do relógio: de como o pessoal se organizou para aquele ato, como enfrentou a polícia, como se construiu solidariedade para com os indiciados e de como os destroços do relógio vieram parar no CV. E isso já remete ao outro evento de organização autônoma dos estudantes que precisa ser rememorado.

\subsection{O CENTRO DE VIVÊNCIAS}

Como relatei alguns parágrafos acima, presenciei vários embates entre os estudantes e a administração do Campus por conta de espaços que estando tradicionalmente destinados para a sociabilidade de estudantes, cada vez mais eram requisitados pela Prefeitura do Campus para serem alugados por empresas, desde serviços de reprografias, até bancos, passando por restaurantes. A polêmica em torno desses aluguéis e cedências era grande, pois a Prefeitura argumentava que os espaços eram mal utilizados pelos alunos: ficavam ociosos, inseguros, depredados, acontecendo a venda de bebidas alcoólicas e o uso de drogas ilegais; alegava também que disponibilizando esses espaços para a iniciativa privada, aumentaria a renda do campus e a oferta de serviços à população universitária. Os alunos faziam sua réplica dizendo que os fins 
primários desses espaços se mantinham, quais fossem, uma referência para a mobilização estudantil, para organizar a confecção de carteiras de transporte universitário, congressos e seminários estudantis, um espaço de debate de ideias, mas também defendiam a possibilidade do desdobramento no usos desses espaços para fins lúdicos, ou mesmo para a disponibilização de outros serviços para os estudantes (como reprografias, livrarias ou videolocadoras autônomas) à baixíssimo custo e com o aluguel pago aos centros estudantis.

Contendas desse tipo ocorreram sobre o espaço de vários centros acadêmicos (Letras, Geografia, História, Biologia, Filosofia), com finais variados, em alguns casos os alunos conseguiram resistir por mais tempo, em outros foi negociada uma realocação, em outros foram simplesmente despejados. Mas a questão do CV foi uma das contendas mais emblemáticas e frutífera desse período.

O CV é um espaço dos estudantes do Campus do Vale, pelo menos desde os anos 1980. Em 1999, metade do amplo local ainda era cedida a uma lancheria/restaurante e a outra metade, construída como uma espécie de anfiteatro, destinada ao uso dos estudantes.

A coisa foi acontecendo aos poucos, fruto da necessidade, do oportunismo, da demanda e da oferta. A lancheria/restaurante começou a servir almoços, sendo que o Restaurante Universitário e os outros dois restaurantes privados pareciam não estar dando conta da procura. No começo as mesas ocupavam apenas o espaço já utilizado pelo empreendimento, mas um belo dia, havia aumentado o número de mesas, então também colocadas na parte baixa, na metade na qual era o "anfiteatro". E um dia depois, o dono da lancheria afastou uns estudantes que estavam ocupando o espaço para uma reunião ou um ensaio. Esse foi o "estalo" para nos darmos conta que se não agíssemos logo, perderíamos toda a possibilidade de uso do CV.

Naquela semana ainda, isso era abril ou maio de 2001, de "boca a orelha" passou a informação de que ocuparíamos o CV. Prontamente, estudantes do IFCH, da Biociências, da Geociências e de outros institutos, se organizaram para permanecer em grande número no local, dezenas, sem necessariamente impedir o funcionamento da lancheria, mas constrangendo a clientela pela nossa presença. Entramos em um regime de assembleia permanente, realizando uma série de oficinas, shows e discussões, e sempre a partir das $17 \mathrm{~h}$ realizávamos o balanço das atividades do dia e a programação das próximas atividades. Chegamos a ter algumas conversas preliminares com a Prefeitura do Campus, mas por conta da greve de 2001 (que abordarei a seguir), quando o 
calendário foi regularizado a ocupação do CV já era um fato consumado. A lancheria foi realocada em novo espaço no prédio da Biociências.

Um ano entre a quebra do relógio e a ocupação do CV. Nesse período acumulamos táticas, narrativas, ações e palavras. Assembleia, ação direta, horizontal, libertário, Proudhon, Bakunin. Esses conceitos e nomes tendo cada vez mais sentido para vários de nós. Aqueles veteranos anarquistas do Tendências Autônomas começaram a realizar encontros de formação; aos sábados no gramado no eixo central do Parque Farroupilha se reuniam com alguns interessados para discutir algum texto basilar. Eu passava ao largo, naquele momento me parecia muito estranha a proposta especifista de criação de uma minoria ativa dentro de movimentos sociais, algo como um partido (?) anarquista; e, como escrevi há pouco, eu passava ao largo, estava começando a me interessar pela leitura dos Mil Platôs (DELEUZE \& GUATARI, 1995-1997) e um amigo me comentava sobre um livro "muito doido", chamado TAZ (BEY, 2010), de uma figura enigmática, conhecida como Hakim Bey (só anos depois fui saber que esse é o pseudônimo do historiador Peter Lamborn Wilson). Enfim, naquele período, eu estava conhecendo mais o Anarquismo Ontológico.

De lá pra cá o CV é totalmente gerido de forma horizontal por coletivos de estudantes (isso já faz 16 anos). Obviamente existem altos e baixos na gestão desse espaço. O primeiro grande desafio foi em 2004 quando membros daquela gestão do DCE resolveram criar uma subseção do Diretório lá no Campus do Vale; num determinado dia, amanheceram lá, ocupando uma sala que ficava no mezanino. Quando os alunos do noturno chegaram (a maioria dos articuladores do espaço era desse turno), houve um princípio de tumulto, por conta da ilegitimidade da ação do DCE. No decorrer dos dias, a Prefeitura Universitária entrou na discussão, na figura de um funcionário que veio mediar o conflito, por conta disso realizamos uma assembleia dos interessados que resultou na expulsão dos membros do DCE do espaço.

A "crise" gerada pela tentativa de instalação de uma representação do DCE no local, serviu para que os alunos que estavam gerindo o espaço sentissem a necessidade de criar um projeto mais estruturado (leia-se escrito e planejado, a médio prazo, sendo menos "espontaneísta)". A partir daí se recriou o espaço como uma espécie de centro cultural, com aqueles serviços autônomos (ilegais para a "lei") que estavam sendo expulsos dos centros acadêmicos (reprografia, videolocadora, livraria) sendo temporariamente transferidos para lá; houve uma iniciativa de oficinas de informática para crianças da vila vizinha do Campus; depois, houve oficinas semanais de capoeira e meditação. Na primeira 
festa organizada nessa "repaginação" do CV, os restos do relógio dos 500 anos, que estiveram no espaço do CECS por alguns semestres e depois desapareceram, estavam lá, como peça principal de uma exposição de objetos de arte confeccionados pelos estudantes; alguém disse: "A quebra do relógio e a ocupação do CV são batalhas da mesma luta"!

Todas essas atividades tiveram a sua duração, mas acabaram sendo descontinuadas por dificuldades dos próprios realizadores. Faz uns 5 anos, o CV passou por um período "meio decadente", com muitas pessoas nem sabendo mais dos primórdios como espaço autônomo, mas então um novo coletivo trouxe para si a responsabilidade de levantar a bandeira da revitalização das ações e da memória ligada ao lugar. E o espaço segue com muitas oficinas, atividades, pelo menos uma grande festa anual: o Festivale. E assim segue como espaço de vivência libertária.

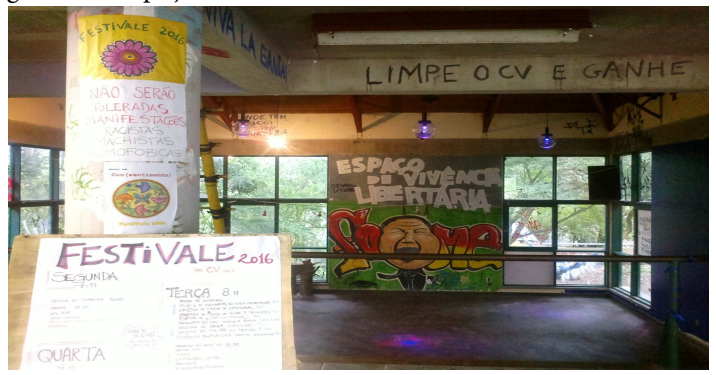

Figura 1: Foto do CV em 2016. Fonte: autor desconhecido, retirada da página do Facebook: CV Vale ${ }^{5}$.

\subsection{A GREVE ESTUDANTIL DE 2001}

Pouco mais de um mês depois da recuperação do CV, tivemos que nos deparar com outro processo bastante sério: a greve das IFES de 2001, uma das 5 maiores da história, com duração superior aos 100 dias. O contexto de sucateamento das universidades, pouco incentivo aos auxílios estudantis, sobretudo na pesquisa e extensão, defasagem dos salários dos servidores, priorização de investimentos no FIES e um todas desrespeito pelas pautas reivindicatórias das categorias bases do funcionalismo federal, foram a realidade dos mandatos de FHC.

A UFRGS recém estava regularizando o calendário acadêmico, alterado pela greve de 1998 (que também esta na lista das mais longas), quando os

5 Disponível em https://www.facebook.com/CV-Vale-1756661074613835/. Acesso em 14 de abril de 2017. 
servidores deflagram uma nova jornada de lutas, os professores ainda demoravam para aderir à greve (o PROIFES é a entidade que agremia a parcela majoritária da categoria nessa universidade) e desde a assembleia geral do estudantes convocada pelo DCE em 08 de agosto, os estudantes se solidarizaram com os servidores e decretaram greve estudantil, com pauta própria. Assim, ajudamos a fechar o Campus Centro e lá criamos um acampamento, onde, nos melhores momentos, permaneceram acampados mais de uma centena de alunos, realizando shows, oficinas e diversas outras atividades.

No começo, logo após a primeira assembleia discente, tanto o DCE, quanto os estudantes ligados as juventudes partidárias estavam de acordo com o acampamento, suas pautas e seus acordos. Ainda na primeira semana fizemos o trancamento de alguns semáforos ao redor do Campus Centro e a mídia televisiva veio acompanhar nossa mobilização. Tínhamos acordado na assembleia anterior que nem o Comando de Greve Estudantil, nem nenhum grupo dentre os discentes, estaria autorizado a fazer qualquer declaração que não fossem as oficiais produzidas pelas comissões de divulgação e relações. Mas bastou aparecer um repórter da RBS para que alguns estudantes ligados ao PT e ao PSTU (aqueles mesmos veteranos que controlavam o CECS anteriormente) fizessem fila para serem entrevistados. Isso causou uma má impressão generalizada, pois o tom de horizontalidade, de descentralização das decisões, a negação de representantes com plenos poderes, valendo-se do apelo midiático ou do uso das estruturas de partidos, foi a linha de corte de como estava sendo organizado o acampamento grevista estudantil em relação aos mesmos modelos de sempre. A ação daqueles estudantes, vistos por muitos como militantes profissionais, feria qualquer dos acordos que tinham sido estabelecidos.

Por isso na mesma noite foi realizada uma assembleia de pauta única, dedicada a ratificar os parâmetros de ação acordados anteriormente e a pedir a retratação dos indivíduos que falaram com os repórteres, lhes exigindo o compromisso com os acordos do movimento estudantil, independentemente da "linha" que o partido lhes passasse. Foi uma assembleia movimentada, muitos políticos importantes foram assistir o que decidiríamos, de certa maneira os rumos da nossa mobilização seriam reavaliados naquele momento e isso poderia influir nas relações dos partidos com suas juventudes e com os potenciais jovens eleitores universitários.

O aluno vinculado ao PT, que fazia parte da direção do DCE, pelo menos taticamente, reconheceu seu erro e comprometeu-se a respeitar os acordos 
estabelecidos nas assembleias do acampamento, bem como agir como delegado do acampamento nas comissões de negociação. O pessoal do PSTU não agiu da mesma maneira, quis colocar dirigentes para falar e se negou a referendar os acordos coletivos, fazendo suas intervenções de forma muito autoritária. Mesmo esteticamente já "chocavam": se inscreviam para falas seguidas, nas quais discursavam com voz alta e gestos nervosos, repetindo as mesmas sentenças, todos estavam usando coturnos.

Durante a assembleia, houve momentos mais tensos em que se teve até que separar os antagonistas, sempre alguém do PSTU e algum libertário. Num desses momentos, um militante do PSTU disse: "Mas desse jeito não dá, se for pra continuar nessa linha então a gente racha, saimos do acampamento, é isso que vocês querem?”. Não era o que se queria, mas já que eles deram a deixa... O acampamento não rachou, mas o PSTU saiu dele e começou a fazer a sua mobilização paralela ao restante do movimento estudantil. Encontrei na rede um comunicado daquele período, "Acampamento de greve dos estudantes da UFRGS: um repúdio ao autoritarismo", de 31 de agosto de 2001, e penso ser oportuno compartilhar ao menos um trecho ${ }^{6}$ :

\section{[...]Não estamos nessa greve a passeio!}

Nossa intenção não é, nem apoiar simplesmente a greve dos servidores, nem estar acampados para formar um clube de festas e debates, como afirmou o grupo Rompendo Amarras/PSTU. Queremos construir juntos uma pauta de reivindicações estudantis e lutar por elas.

É claro que, para isso, é necessário reconstruir o Movimento Estudantil, e essa reconstrução só pode se dar a partir do comprometimento de todos os estudantes. No entanto, esse grupo Rompendo Amarras assumiu a postura de boicotar o movimento por não poderem controlá-lo ou dirigi-lo. Redimem-se da responsabilidade em relação a qualquer deficiência desse movimento, do qual eles também fizeram parte. Exemplo disso é a recente divulgação de um panfleto que difama o acampamento.

Estamos construindo um movimento plural e coletivo, por isso temos trabalhado no sentido de dialogar com as diferenças de forma a consolidar uma unidade na prática. Contudo, esse ideal não tem sido compartilhado por todos. Infelizmente, essa perspectiva de construção a partir da pluralidade não é compreendida pelo bloco "Rompendo Amarras/PSTU". Esses colegas boicotam qualquer forma de construção coletiva de baixo para cima, mostrando-se incapazes de aceitar a igualdade na discussão e na prática. Ou seja, de forma totalitária e

6 Mantida a formatação original, disponível em

http://brasil.indymedia.org/eo/red/2001/08/5888.shtml, acesso em abril de 2017. 
antidemocrática, esses colegas estão boicotando o acampamento que eles mesmos contribuíram para a construção. Exemplo central dessa postura sectária foi a traição praticada por membros do bloco/partido, que, participantes da comissão de divulgação do movimento, se dispuseram a representar o movimento estudantil no Campus do Vale, na reunião com bolsistas do dia 28/8 e na panfletagem no RU. Lá chegando, trocaram suas camisetas, fardando-se com as camisas do Rompendo Amarras/PSTU, e espalharam um panfleto mentiroso e inconsequente, difamando e negando a importância e a seriedade dos estudantes do acampamento. Tudo isso aconteceu porque - pela primeira vez - a direção é de todos.

VENHA VOCÊ MESMO AJUDAR A CONSTRUIR O MOVIMENTO DE FORMA DESCENTRALIZADA!

\section{MOVIMENTO ESTUDANTIL PELA EDUCAÇÃO}

(DCE - DA'S - CA’S - Comissão de Mobilização/UFRGS)

Entendo que a carta traz em si um pouco do sabor (saber, para BARTHES, 2006) daqueles dias. Mais de 100 dias de mobilização, grande parte deles acampando em um Campus ocupado, vivendo o processo das comissões, das assembleias, das oficinas e, porque não, das festas. De forma que esse foi mais um evento marcante na minha trajetória de inquietação autonomista. A greve terminou, as barracas foram recolhidas, mas algo que antes não tinha uma expressão tão clara ficou.

Eu queria é mais desse formato e das sensações que ele me causou. Para mim essas experiências foram como um ensaio do que é uma comuna, e o impacto desses eventos sobre mim é algo como o descrito por Hakim Bey em TAZ:

[...] Do nosso ponto de vista, o principal elemento de fascínio é o espírito das comunas. Durante e depois destes anos, os anarquistas adquiriram a prática do nomadismo revolucionário, perambulando de revolta em revolta, procurando manter viva em si mesmos a intensidade do espírito que eles experimentaram no momento do levante. $\mathrm{Na}$ verdade, certos anarquistas da estirpe stirneriana/nietzscheana encontraram nessa atividade um fim em si mesmo, um modo de sempre ocupar uma zona autônoma, a zona intermediária que se abre no meio ou no despertar de uma guerra ou revolução (cf. a "zona" de Pynchon em Arco-Íris da Gravidade) [...]. (BEY, 2010, p. 49)

\subsection{O DCE É TU!}

De revolta em revolta saímos da greve e voltamos as questões cotidianas do Campus do Vale. Voltamos nossas atenções ao CECS LIVRE, que no final da 
gestão teve uma prestação de contas cômica e vergonhosa, dada à pouca inclinação para questões financeiras de todos os seus membros, o que acabou comprometendo a imagem dessa experiência, vista como pouco séria. E na sequência, ocupou-se um espaço abandonado no campus, conhecido como "Estufa", para se realocar o CADAFI (Centro Acadêmico da Filosofia), posto que o espaço destinado para o mesmo é minúsculo. Essa ocupação durou alguns anos, até que foi trancada a entrada do prédio e colou-se seguranças no perímetro do mesmo; mais de 13 anos depois, fico sabendo que uma nova safra de alunos da filosofia reocuparam esse espaço. Em meio a tantas pautas e lembranças o que realmente quero deixar registrado é o clima de agitação política autônoma realizada pelos estudantes da UFRGS naqueles anos, o que desencadeou a composição de uma chapa para as eleições do DCE é do ano de 2002, o "DCE é tu!".

O "DCE é tu!" foi a primeira e única gestão apartidária, autonomista e à esquerda do Diretório Central de Estudantes da UFRGS. Essa gestão teve duração entre final de 2002 e final de 2003 e embora tenha sido uma campanha diferenciada e, como estou relatando, o ambiente político estivesse favorável, não acreditávamos que que havia a possibilidade real de ganhar a eleição, mas isso aconteceu.

Me lembro bem do período de campanha, desde o começo foi pautado que embora houvesse a necessidade de inscrição de nomes específicos para os cargos da gestão, que o trabalho todo seria realizado em comissões. Durante a campanha, o nosso método de propaganda e de construção da proposta de gestão era o de reuniões abertas de debates, assembleias, das quais se iam incorporando os pontos que os participantes entendiam como os mais relevantes. Nesse contexto, as propostas mais "tresloucadas" eram reestruturadas e lapidadas até se adequarem a realidade.

Pessoalmente eu participei pouco desse Movimento, nesse período estava encerrando a minha graduação e me concentrei no trabalho de conclusão, além disso estava mudando para a zona rural de uma cidade próxima a Porto Alegre, o que dificultava o meu envolvimento com as demandas do coletivo gestor.

Busquei algumas lembranças com de colegas que foram mais ativos nesse processo. Em depoimento por e-mail (dada a distância geográfica), entre outros pontos, Larissa me relatou que:

O "DCE é tu" foi no segundo semestre de 2002. Lembro que era bixo e de repente me vi no CEUE [o diretório da Engenharia] fazendo cartazes. De repente foi a votação, creio que em final de agosto, um frio danado. Sentamos nas 
escadarias da SAE e esperamos o resultado. Quando saiu ninguém acreditou. Era um misto de alegria e surpresa, porque era um momento novo na política estudantil, do conceito de representação para o de ação. (Larissa, socióloga, 33 anos, depoimento por e-mail em maio de 2017, grifos meus)

A última frase desse trecho das memórias de Larissa me parece paradigmática; para a nossa geração, estávamos vivendo um novo momento, menos representação e mais ação, mais participação. Noutro momento de seu depoimento, Larissa aponta que:

Tava lembrando da primeira reunião. Umas 80 pessoas sentadas em círculo, buscando construir ideias distintas sobre prioridades e o que o DCE deveria atender. Até que no meio da discussão alguém lembrou: "Mas o DCE não é tu? Ponha a mão na massa! Bota fé?" [frase de Rodrigo, um grande articulador dentro do movimento]. E a partir dessa ideia surgiram diferentes frentes de trabalho autônomas. Congregava desde anarquistas, cristãos, ambientalistas e autonomistas. Tudo isso foi reflexo e se refletiu na participação do movimento estudantil da UFRGS nos eventos que antecederam a edição do Fórum Social Mundial de 2003, em diálogo com diferentes movimentos sociais e novas formas de articulação via tecnologias digitais. (Larissa, socióloga, 33 anos, depoimento por e-mail em maio de 2017, grifos meus)

Larissa citou Rodrigo outro aluno das sociais que esteve vinculado com o Tendências Autônomas, aquele coletivo que comentei ter me causado grande impressão quando entrei na universidade. O Tendências já estava se reformatando e o Rodrigo não militava mais oficialmente nesse coletivo, mas continuou militando no movimento estudantil e trouxe toda a bagagem anarquista que acumulou junto desse coletivo. Ele foi uma figura muito importante na greve estudantil de 2001 e ganhou respeito suficiente para ser um dos principais articuladores do "DCE é tu!" no ano seguinte.

A frase que Larissa recordou da primeira reunião oficial da gestão, tinha a marca registrada de Rodrigo e dos jargões da época (“bota fé?", por exemplo). Mas expressava toda a concepção (pelo menos a que nós conseguíamos imaginar no período) da necessidade da participação, da responsabilização de cada um para que as coisas acontecessem. Infelizmente esse é um gargalo tático, talvez até epistemológico, que tenho enfrentado desde então.

No excesso de tarefas e entretenimentos que temos na sociedade capitalista atual, e na maneira como somos passivos na maioria dessas ações: recebendo ordens, assistindo mídias, controlando o trabalho de máquinas ou de outras pessoas... pouco espaço físico e subjetivo temos para o planejamento e a 
produção autônomos, se ainda somarmos nessa equação o fazer político e sua a gestão executiva, estamos mais perdidos, pois nos faltam referências de como agir politicamente.

Por mais contraditório que possa ser, afinal a política, em algum grau, está em todas as relações humanas. Mas da forma como temos vivido em nossa sociedade, cria-se uma esfera separada para a política, que passa a ser representativa, e alienados que estamos das suas premissas e rotinas, dizemos que a odiamos. Nesse contexto, é mais difícil estabelecer os saberes-fazeres políticos, sobretudo para que possa haver uma mediação e coerência entre os desejos e necessidades individuais e s necessidades coletivas. Ainda mais difícil dentro de uma perspectiva anarquista para um coletivo de dezenas de milhares de pessoas, como os discentes da UFRGS, das quais apenas uma minoria ativa pode, consegue ou quer se identificar como DCE e "botar a mão na massa".

Pragmaticamente vimos isso no decorrer do ano de mandato da gestão do "DCE é tu". A inércia cumpriu seu papel, e quem já conseguia estudar e fazer movimento estudantil, aqueles que eram mais voluntariosos ou de um perfil mais executivo, permaneceram fazendo, mas muita gente debandou logo nos primeiros meses e houve quem agiu de má-fé e se apropriou de dinheiro recolhido pelo diretório ou "fez fama" por sobre o seu cargo. Em seu depoimento, Rodrigo aponta essas questões:

Pois é, começou super bem e depois foi esvaziando. Muitos foram os fatores que levaram a derrocada dessa experiência: despolitização, "umbiguismo", falta de "parceria séria", a dificuldade de organização da militância frente aos compromissos pessoais. Só ao vivo pra expor bem direitinho, mas resumidamente foram esses fatores que complicaram o andamento da gestão. Mas mesmo assim, tem que se saudar o fato de ter sido a única gestão na história do DCE da UFRGS que não foi aparelhada por algum partido politico, dá pra encher a boca e dizer que foi uma gestão $100 \%$ autonomista. (Rodrigo, sociólogo, 40 anos, depoimento por e-mail em maio de 2017)

Foi isso, desses anos de formação é isso que eu tenho a compartilhar nesse momento, buscando estabelecer uma ligação entre a minha experiência biográfica e o campo de possibilidades que se estabeleceu como um continente de práticas e narrativas para uma geração de universitários em Porto Alegre e que levou muitos de nós a insistirmos na busca de experiências libertárias, autonomistas, de militância política e solidariedade. $\mathrm{Na}$ próxima seção continuarei com a narrativa de algumas dessas minhas buscas e encontros na rede autonomista do sul brasileiro. 


\section{EXPERIMENTALISMOS}

No ano de 2003 fui morar no campo, ia e vinha quase todo o dia para Porto Alegre, numa viagem que na melhor das hipóteses demorava em torno de duas horas, mas estava no campo, tendo, mesmo que de forma acanhada, uma experiência de coisas práticas do dia a dia rural que eu mesmo não tinha vivido anteriormente e fazia muitos anos que a minha mãe havia tido esporadicamente.

De fato foi a geração dos meus bisavós que realmente teve uma vivência forte das "lides do campo". Nessa experiência me dei conta de uma pobreza relativa ao campo e de uma pobreza relativa à cidade. Se o campo é pobre de serviços, pela ausência de certos produtos e pela distância para obtê-los, a cidade é pobre de tempo livre, de tranquilidade, de ar puro, de água limpa e fresca, possibilidades de alimentos variados: frutas do mato, PANCs (plantas alimentícias não-convencionais).

Errando pela cidade, excetuando as praças e alguns centros culturais e educacionais, qualquer lugar de parada, de relaxamento, tem que ser mediado pelo consumo, e se você está em trânsito pela noite, você dificilmente escapa de ter que consumir algo. A alimentação consumida é quase toda industrializada, frita e baseada em carboidratos. No ambiente da cidade a maioria de nós se esquece daquilo que Sahlins ([1972] 2004) chamou de afluência original.

Nossa dieta urbana cotidiana convencional não chega a duas ou três dezenas de alimentos, que em sua maioria são milho, trigo, soja e carne processados; e mais, a maioria de nós perdeu completamente a referência do ciclo de produção e distribuição da maioria dos alimentos que consomem. Enquanto que em seus contextos tradicionais, populações nativas e camponesas consomem e produzem até centenas de plantas, carnes de caça e derivados animais e fermentados, compassados com os ritmos dos ciclos naturais. Alimentos e ritmos que perdemos. Caminhar com a minha mãe pelo campo, sendo uma experiência singular de humildade, descobrindo todas as saladas e chás que ela conhece e aos quais eu era totalmente cego, embora ainda seja muito ignorante.

A abertura para perceber isso, me fez querer saber mais sobre esses saberes práticos do cotidiano, menos teoria e menos cultura do entretenimento e mais saberes técnicos ligados à alimentação, à moradia, ao uso das energias disponíveis na natureza (a combustão da madeira, a força da água e do vento...). Os recursos básicos para se viver a vida fora do trabalho assalariado do contexto urbano. 


\subsection{O UM DE NÓS}

Não estive sozinho nessas "viagens", tive um companheiro e um guia nessa cruzada bricoleur, aquele veterano de índole tempestuosa e maníaca sobre o qual comentei de passagem na introdução da seção anterior. Ele acabou sendo meu vizinho no campo, morando a não mais que cinco quilômetros da minha casa, distância que algumas vezes venci a pé. Sua casa, que carinhosamente chamávamos de rancho, passou a ser a base dos nossos experimentalismos. A nossa "bíblia" era o Manual do Arquiteto Descalço (LENGEN, 2014), e no rancho construíamos, derrubávamos e reconstruíamos modelos de utensílios, móveis, paredes, revestimentos.

Enquanto íamos construindo, íamos conversando e teorizando tudo, oscilando entre a verborragia e o caos linguístico e a metodologia reflexiva da indução e dedução. Desde o começo, não fomos só os dois, outras pessoas, de nossas relações próximas também estavam na mesma busca, então nos finais de semana vários amigos (às vezes quase 20) se acercavam do rancho para fazermos essas construções e com elas experienciar várias outras práticas: luaus madrugada a dentro; cozinha experimental; oficina de montagem e reforma de bicicletas, rodas de capoeira; busca de referências das sabedorias ameríndias, sobretudo Guarani e Kaingang; quebra dos paradigmas formais de sociabilidade. O feminismo, por exemplo, em si já era uma questão, mas no nosso grupo era problematizado de uma forma talvez mais ingênua que na atualidade. Para muitas "minas" que estavam naquele grupo, o poder andar sem camisa, como os meninos, e eventualmente mudar de parceiro dentro do grupo de afinidade mais estreito, sem ser tachada disso ou daquilo, já era um pico de empoderamento.

Nos quatro anos seguintes, o grupo crescera e só o rancho não comportava mais espacialmente tantas pessoas e tantos experimentos. Alguns de nós estávamos na pós-graduação e começamos a nos cotizar para comprar um terreno maior, pois apesar de estarmos na zona rural, estávamos em um terreno, um pouco maior que a metragem urbana convencional e dentro de um loteamento. Nesses anos surgiu uma gíria entre nós, um pouco inspirada na ideia de rizoma (DELEUZE \& GUATARI, 1995-1997). A ideia era que cada um dos terrenos que comprássemos seria um nó em uma rede mais ampla, de vários nós, mas ao mesmo tempo "um de nós", alguém do nosso grupo podia iniciar algum projeto, algum experimento.

Pesquisamos muitos lugares tanto da região metropolitana quanto do litoral e por fim conseguimos comprar algo. Mas aí o problema foi o dinheiro 
para conseguir colocar estruturas permanentes, a disponibilidade de tempo da maioria das pessoas envolvidas, mais uma vez a realidade financeira e as rotinas acadêmicas refrearam as possibilidades que estavam sendo ensaiadas. $\mathrm{O}$ terreno maior acabou sendo cada vez menos usado até que o vendemos.

Outro elemento importante nos processos que deixaram inerte aquela configuração mais politizada do "Um de nós" foi, justamente o temperamento do "Rapaz Tempestuoso", outras configurações surgiram, mas ao meu ver, não na mesma intensidade. Por ora basta relatar que para alguns dos membros daquele proto-coletivo o personalismo e a intensidade do nosso anfitrião foram determinantes para saturar a paciência alheia. Em grupos espontâneos e informais há uma tendência ao personalismo, ou construção de parentescos rituais entre os afins. Mas esses afins são/estão afins a partir do quê? O que os move? Se pode aceitar o peso de personalidades egocêntricas em prol de uma vivência, de uma busca utópica? Não é recair nas velhas e opressivas estruturas das quais queremos nos autonomizar?

Nem tudo foram flores, mas também não houve só espinhos nessa experiência. Mais uma vez temos a volta daquele sentimento que ilustrei através da citação de Hakim Bey (2010): “(...) os anarquistas adquiriram a prática do nomadismo revolucionário, perambulando de revolta em revolta, procurando manter viva em si mesmos a intensidade do espírito que eles experimentaram no momento do levante (...)". Rapidamente construirei uma cena etnográfica que aborda o meu encontro com um ex-membro do "um de nós", procurando resgatar um pouco do sentimento que ele tem por essa experiência formativa.

\section{Cena etnográfica 1: conversa com "Andarilho do Asfalto" em uma okupa punk em Porto Alegre, janeiro de 2016}

Estava rolando um evento de tatuagem no qual o dinheiro arrecadado seria destinado para ações ligadas com a Cruz Negra Anarquista (frente solidariedade à população carcerária, ideologicamente militando pelo abolicionismo penal). Já tinha ido alguns vezes nessa okupa, mas não tinha encontrado o "Andarilho do Asfalto", embora ele estivesse morador desse espaço. Me aproximei para "trocarmos uma ideia". Fazia muitos anos que eu não o encontrava. Ele era um guri que "colava" no rancho, estudante da graduação em Sociais quando eu já estava no doutorado. Era um entusiasta da capoeira, dos malabares e da bicicleta como filosofias de vida. Um belo dia ele deixou de ir aos mutirões e eu descobri que ele tinha iniciado uma viagem de bike e de carona até a Bahia. Ele que já circulava na cena punk de POA, acabou ficando em squats no Rio de Janeiro e em Salvador. Durou quatro anos essa viagem dele. 
- Um contato vai levando à outro. Você conhece uma pessoa na estrada e ela te indica alguém ou algum lugar na cidade e assim vai indo. Na noite também tu já saca o jeito de algumas pessoas, de alguns lugares, e te acha.

Continuamos a conversa e ele me disse que tava a fim de dar um rolê maior, de procurar um lugar com calma pra fixar residência, de repente com um outro coletivo.

- Aqui já deu o que tinha pra dar, sou muito agradecido ao pessoal dessa okupa, adoro as crianças, mas entraram uns elementos novos e o grupo não tem mais confiança dentro dele mesmo [lágrimas nos olhos]. Agora é preparar o espírito e voltar pra estrada!

- Deve ser difícil a estrada, tanto tempo, as caronas que não acontecem, a incerteza...? - perguntei pra ele.

- É, e não é. O meu objetivo agora é ir só de bike e eu estou treinando o desapego, precisar cada vez menos das facilidades que tem na estrada. Pra ti ter uma ideia, o posto de gasolina é um lance que vicia. Eu chego a sonhar, me dá uma ansiedade quando eu vou chegando perto de um posto de gasolina na estrada, porque ali eu sei que vai ter um banho, uma comida quente e um lugar pra dormir. E isso é bom, mas deixa o cara preguiçoso, sem motivação pra fazer por si mesmo e aí continua nas migalhas do sistema.

Inevitavelmente a conversa navega pra rede, pros amigos em comum. E ele me pergunta sobre o "Rapaz Tempestuoso". Eu lhe atualizo sobre seu paradeiro, sobre os novos projetos. Falamos sobre uma outra terra que ficou parada na campanha. Lamentamos, sinceramente, esses reveses da vida e então ele comenta:

- O rancho foi uma escola pra mim, aprendi muita coisa lá. Foi ali que me despertei para vários desses "corres" que até hoje vou levando. Foi lá que acreditei que podia fazer o meu caminho de forma diferente e tive coragem e incentivo pra cair na estrada; que fui me treinando pra viver o anarcoprimitivismo [movimento do qual uma das principais referências é o filósofo John Zerzan] como tenho feito desde de então com os anarkopunks com os quais eu colo.

Assim, um fruto positivo da experiência do "um de nós" foi instrumentalizar um série de pessoas para aceitarem a sua especificidade autonomista e libertária e para outras práticas alternativas ao regime de produção e consumo do meio urbano-industrial moderno. Interessante notar que quanto mais fazíamos esses experimentos, mais pessoas que também estão nesse tipo de experimentalismo encontrávamos. A tessitura da rede cada vez mais reforçada. 


\subsection{O FACA-VOCÊ-MESMO E O ROLÊ ANARQUISTA DE PORTO ALEGRE}

A partir de 2005, através do "Rapaz Tempestuoso", conheci três outras pessoas que me levaram a ter uma visão mais profunda da dimensão teórica do anarquismo, de suas experiências práticas e das redes que em Porto Alegre, que se não eram propriamente anarquistas, estavam recheadas de pessoas com tendências, pelo menos, ao autonomismo. Vou identificar esses três pelas alcunhas de "Enxaqueca", "Traça" e "Bit".

O primeiro trouxe um grande know-how advindo de sua relação anterior com o Coletivo Sabotagem, um grupo descentralizado e anucleado, de indivíduos que militam dentro do movimento anticopyright, pela difusão livre de artes, tecnologias e produtos, digitalizando e distribuindo na rede uma série de materiais; esse grupo atuou publicamente nos anos 2000, depois recolheu-se em um silêncio tático por conta da exposição midiática e investigação policial, posto que as empresas editorais não ficaram nem um pouco contentes com o trabalho deles. "Enxaqueca" unia em si muitos conhecimentos do mundo do cyberativismo e de várias vertentes do anarquismo, do clássico ao contemporâneo, do social ao individualista. A isso se juntando uma "pegada antropológica" e uma veia empirista/realista bastante positivas, trazendo mais um sabor à mistura das pretensões que eu e o "Rapaz Tempestuoso" buscávamos implementar.

"Traça”, uma pessoa pessimista, fumante inveterado, gênio da feitura artesanal de livros. Circulava pelo Campus do Vale vendendo suas cópias autônomas de determinados livros esgotados. Com o incentivo e as "parcerias" certas passou a publicar títulos copyleft e traduções inéditas, algumas livres de direitos autorais e outras nem tanto. Seu exemplo foi importantíssimo para que um grupo de jovens aprendesse o essencial da ideologia faça-você-mesmo aplicada à gestão de empreendimentos livreiros e fundasse a Editora Deriva, especializada na edição de livros anarquistas para o mercado brasileiro, que para além da sua linha editoral própria, também edita e imprime material para outros coletivos a baixos custos.

E pra fechar a tríade, "Bit", punk nerd dos computadores. Legal, tranquilo. Completamente ligado na última tendência de softwares livres e do punkcore finlandês (se é que isso existe). Não tem o que falar muito dele, sempre foi um sujeito de um perfil mais quieto, menos articulista do que o "Enxaqueca", menos empreendedor que o "Traça", mas bastante pé do chão e um executor pragmático daquilo que lhe interessasse. 
A partir dessas três figuras é que se abriu pra mim todo um mundo de informações, agendas e contatos ligadas aos universos do infoativismo, do façavocê-mesmo, do software livre e do hardware livre, tudo isso desde uma forte perspectiva de anarquismo. Foi um ganho considerável na minha trajetória, pois apesar de tudo o que estava experimentando com o "um de nós", parecia que estávamos muito isolados, que era pouco efetivo, muito onírico, difícil de materializar muitas das questões que estávamos nos propondo. Naquele novo momento, as coisas adquiriam consistência, a rede cresceu, o horizonte libertário e autonomista ficou maior.

Desde então realizou-se em Porto Alegre duas edições do projeto intitulado videoativismo: "Mostra Videoativismo no Cinema: do capital globalizado aos movimentos antiglobalização" (entre maio e junho de 2007) e "Videoativismo no Cinema: fronts de uma guerra midiática". Esses eventos foram apoiados pela Editora Deriva e tiveram o suporte institucional de professores ligados ao Departamento de História da UFRGS, por conta disso pudemos utilizar as dependências da sala de cinema da universidade na $1^{\text {a }}$ edição e o auditório da Escola técnica na $2^{\text {a }}$ edição.

Participei como comentador do filme Surplus (de Erik Gandini, ano da produção: 2003) na primeira edição. Foi nessa atividade que eu comecei a me relacionar com os punks da okupa na qual reencontrei o "Andarilho do Asfalto" (como relatei na cena etnográfica 1).

\section{Cena etnográfica 2: Intervenção dos punks durante o debate do filme Surplus. Porto Alegre, maio de 2007}

$\mathrm{O}$ videoativismo não era pra ser um evento universitário, mas era dentro da universidade e muitas das pessoas da rede que o estava organizando eram estudantes. A galera alternativa, ligada com o "massa crítica" (evento de promoção da cultura ciclista), os clientes e apoiadores da Deriva, os alunos dos cursos de ciências sociais e história, todos esses grupos estavam presentes. E tinham os anarcopunks, que formavam um grupo diferenciado. Havia dois grupos deles, que pareciam fazer questão de estarem em espaços diametralmente opostos (posteriormente fui entender que membros de um coletivo já tinham participado do outro, mas houveram desentendimentos e a saída não foi muito amistosa). Vestiam roupas pretas, jeans, collant e couros; rasgados, remendados, com tachinhas, bottons e patches (remendos de panos com inscrições políticas ou de bandas), bandanas vermelhas e pretas. Tinham zines e panfletos expostos em panos estendidos no chão. Estavam com suas crianças também, que brincavam pelo espaço. Ao final da exibição do filme, eu e mais um colega, 
alunos do PPGAS/UFRGS, iniciamos um debate sobre o filme. Um dos punks, se levantou e começou a falar:

- Achei bem legal o que o pessoal tá falando. A gente não tem umas palavras bonitas assim, não passou pela universidade, mas a gente tem a vivência true mesmo, a vivência da rua. A gente é anarcoprimitivista antes de inventarem esse termo. O Zerzan [John Zerzan, um dos entrevistados do filme] tá certo, mas ele não tem, não conhece, a riqueza das nossas periferias, de trocar uma ideia com o tiozinho, com a tiazinha da vila... Nós também temos nosso amigos Guaranis e Kaingang e aprendemos muito com eles... O pessoal fala que programa de índio é furada, mas coisa bem boa fazer um programa de índio. É isso aí pessoal, já falamos demais.

Desde então me habituei a ver e reconhecer esses punks em diversos "rolês", nas rodas de capoeira Angola; ajudando a recolher as barracas de feiras, em troca de produtos da xepa; divulgando seus zines em pontos estratégicos do centro. Passei a conhecer as tretas com os neo-nazi: "Meu, te liga na região do [Bar] Garibaldi hoje, tá lotada de nazi!". Toda uma outra geografia de Porto Alegre, atravessada de bicicleta; com outros códigos (cartazes, pixos, grafittes) e outros atores que eu imaginava, mas só então passei a identificar na algazarra urbana. Muito me interessou, também, esse hibridismo do estilo punk europeu, politizado e "anarca", igualmente fã e/ou músico de punk rock e hardcore, vegetariano ou vegano, mas também capoeirista e interessado em cultivar relações com os indígenas locais, inclusive conheci uma família punk em que a mulher era de ascendência Guarani.

A ocupação desse grupo ficava em um galpão industrial abandonado em ruínas na Zona Oeste da cidade. Fomos “Traça, "Enxaqueca” e eu, levar um material para uma construção que eles estavam fazendo. A "casa" era formada por várias peças reconstruídas com técnicas de bioconstrução, ou com entulho empilhado, algumas particulares e outras de uso comum. Tinha uma horta no espaço e "Enxaqueca" pagou um exame de amostra do solo, que o resultado foi o de altamente contaminado por chumbo. Apesar de ter me tornado habitué de vários rolês deles e vice-versa, nunca consegui saber quantos eram do núcleo básico dessa okupa, os moradores sempre estavam mudando, ou partiam em longas viagens e, um belo dia retornavam, como no caso do "Andarilho do Asfalto". Poucos falavam com os não-punks, sobretudo as mulheres eram mais reservadas, só quatro homens eram mais receptivos e abertos ao diálogo. $\mathrm{Na}$ verdade eu me sentia bastante alienígena, com um misto de vergonha por não ser tão "raiz" quanto eles, e sentia um certo orgulho ferido, como se eles 
estivessem zombando de mim. E no entanto, as relações seguiam, fizemos várias trocas econômicas, de conhecimentos, de solidariedade e houve até uns namoros entre membros do grupo ligado à Editora Deriva e daquela okupa.

Depois dos encontros sobre "videoativismo", realizamos uma série de outras atividades, que valem ser rememoradas, mesmo que rapidamente. $\mathrm{O}$ "10 Colóquio de Educação Libertária”, ocorrido em outubro de 2009, nas dependências da FACED/UFRGS, por ocasião dos 100 anos da anos da execução do pedagogo anarquista espanhol Francisco Ferrer y Guardia, idealizador da Escola Moderna, que incluso influenciou várias escolas pelo Brasil, entre elas uma em Porto Alegre.

Por três dias vários coletivos e militantes individuais do RS, identificados com a pauta da educação libertária, debateram a questão a partir do aporte de pesquisadores simpatizantes ou identificados como anarquistas, fora as contribuições (não menos importantes) locais, recebemos a visita de Doris Accioly (FEUSP), Edson Passetti e Acácio Augusto, ambos do NUSOL/PUC-SP. A primeira trouxe uma reflexão sobre a importância de Ferrer y Guardia no desenvolvimento da pedagogia. Interessante que durante o ano de 2016 pude reencontrá-la por ocasião de uma conferência que organizamos na UFFS Campus Erechim sobre a obra e o pensamento de Maurício Tragtenberg, de quem foi discípula, atualmente sendo como que zeladora de seu espólio intelectual. Já Passetti e Augusto nos brindaram com uma primorosa apresentação sobre a máquina disciplinar analisada por Foucault e dispositivos advindos da guerrilha epistemológica anarquista, muito referenciados na própria trajetória do NUSOL e na melhor performance "odeia-nos ou nos ame".

Desde esse encontro vários colegas, amigos e militantes tem intensivamente se dedicado ao estudo de soluções de educação autônoma e/ou libertária aqui no Rio Grande do Sul. A nossa geração começou a ter filhos, na época do Colóquio faltava um mês para meu filho nascer, e, pelas nossas experiências escolares e aspirações políticas, pensar maneiras de reinventar esse espaço de socialização tão importante nas sociedades modernas. Eu não consegui fugir de entregar meu filho pra creche desde bem novo e de continuar na lógica da educação tradicional. Nem do parto cesárea, por razões de saúde (e por uma certa pressão psicológica da obstetra) a mãe dele conseguiu escapar. Mas um casal de amigos meus conseguiu ter a filha em um parto natural dentro de uma aldeia indígena; outro amigo tem conseguido adiar a entrada da filha no sistema escolar por 4 anos e assim o pessoal vai fazendo o que pode. E as iniciativas tem aparecido: o CLA (Coletivo Liberdade e Autonomia) e a 
Resistência Popular, são grupos que constantemente têm levantado a bandeira da educação em seus locais de militância, seja EJA, seja Pré-ENEM, seja a organização de espaços para oficinas de sensibilização para crianças. A questão é que cada local tem suas tensões e especificidades, como todos os outros projetos, acaba sendo difícil manter o vigor daquela ação por muito tempo, na falta de recursos materiais, na constante ameaça ou de despejo ou de algum poder paralelo (leia-se o "crime organizado") que não vê com bons olhos esse empoderamento da comunidade. Mas, na busca de ajudar na organização autônoma de um grupo ou uma comunidade, na busca de uma experiência de pico (BEY, 2010) que positive o anseio militante, esses lutadores sociais continuam se mobilizando, acumulando problemas táticos e soluções estratégicas para os mesmos, juntando know-how para que venha o dia em que essas ações conseguiram continuar consolidadas a médio ou longo prazo, dentro de uma coerência programática da busca da melhoria das condições de trabalho, vida e organização, semeando a ajuda mútua e a emancipação.

Um evento que podemos dizer que conseguiu criar uma tessitura, tornando-se periódico, esperado e desejado, foi a Feira do Livro Anarquista de Porto Alegre (FLAPOA), que teve a sua $1^{\text {a }}$ edição em 2010 a partir da junção de esforços do coletivo em torno da Editora Deriva e do CLA, além de outros grupos da cidade, bem como pessoas que vieram do interior do Rio Grande do Sul e de outros estados. Sendo que, pelo menos desde o início desse século, Porto Alegre foi uma das cidades pioneiras na organização de um evento anarquista nesse formato, como essa divulgação, apoio e publicidade. Depois de Porto Alegre, várias outras capitais, como São Paulo, Florianópolis, Belo Horizonte e cidades menores como Pelotas, Santa Maria e Guaíba (todas essas no Rio Grande do Sul), também valeram-se desse tipo de evento para promover o encontro de coletivos e simpatizantes, em uma série de debates, venda de livros e zines voltados ao nosso referencial teórico e político e à temas fronteiriço, em sua maioria publicados por editoras locais e independentes.

Outro ponto interessante é que o grupo proponente original da $1^{\text {a }}$ FLAPOA, indicou que para a segunda edição precisaria de que mais pessoas "pegassem junto" e já na $3^{\text {a }}$ edição o comitê de organização era outro bem diferente do grupo da $1^{\text {a }}$ edição. Um pouco disso se deve a dificuldades particulares de alguns membros de realizarem o trabalho em equipe, mas isso acabou sendo benéfico porque, dada a importância que a periodização desse evento teve para a cena anarquista da cidade, muitos coletivos entenderam a relevância de manter a chama acesa e fazer o evento acontecer. Até 2016, a 
FLAPOA estava de pé, sempre com público e uma fecunda troca de ideias.

Tantos outros experimentos, desbravamentos, iniciativas, aprendizagens que circularam por essa rede anarquista, libertária, autonomista. $\mathrm{Na}$ área da alimentação, com influência da agroecologia, agricultura biodinâmica e hortas urbanas na produção, e do vegetarianismo e o veganismo, no preparo. Na busca de tecnologias e técnicas que nos levassem cada vez mais pra fora da grade de serviços, desde o transporte por bicicletas, até bioconstrução, passando pelo software livre. Infelizmente, precisaria de muito mais páginas para resgatar de forma apropriada toda essa vivência, mas tenho que editar muita informação pra poder dar conta do intuito de passar uma visão mais panorâmica de toda essa movimentação.

Na próxima seção trarei, de maneira bastante breve, um comentário sobre o papel das mulheres em toda essa cena de sociabilidade e política.

\section{AS "MINAS" E OS FEMINISMOS NA REDE ANÁRQUICA GAÚCHA}

O fato de até o presente momento dessa narrativa as mulheres pouco terem aparecido como interlocutoras, ou não terem aparecido ações protagonizadas por elas, não quer dizer que elas estiveram ausentes ou foram sem importância nessas vivências, mas existe um ponto de distanciamento, talvez até ontológico, por ser homem, que separa a minha experiência da experiência das mulheres.

Nas experiências que eu relatei na primeira seção do texto, quando abordei a política estudantil dentro da UFRGS, "os anos de formação", poucas meninas participavam do grupo com tendências mais anarquistas e as que participavam, logo entraram em relacionamento com algum rapaz e, sei lá porque, ficaram muito vinculadas à imagem de "a namorada de fulano". Com exceção da Larissa e de uma veterana da filosofia, de nome Denise (que não era tão "agilizada", mas estava sempre presente nas discussões), nenhuma outra menina, na minha percepção pelo menos, tinha uma presença ativista bem marcada, não pelo viés libertário. Existiam "minas" bastante presentes nas questões da política de solidariedade indigenista; na juventude dos partidos eleitorais (PT, PCdoB, PSTU), tinham várias mulheres que eram referências, que estavam organizando as pautas, convocando reuniões etc.. Mas no meio anarquista, seja nos militantes mais sociais e organizados, seja num anarquismo mais individualista e egocentrado (anarcotropicalismo, nós diríamos de troça), as mulheres eram menos manifestas, não sei se menos engajadas, mas menos passíveis de 
identificarem-se e serem identificadas como anarquistas ou libertárias.

Posteriormente, no período mais intenso do "um de nós", chegaram algumas mulheres por si mesmas para participar do grupo e independentemente dos seus relacionamentos, elas eram pessoas importantes per si. Até relatei na seção anterior o "feminismo ingênuo" que existia dentro do grupo, se comparado com o peso das discussões atuais. Mas a partir dessa época eu tinha duas questões que calcaram a forma como eu me relacionava com as demais pessoas que faziam parte desse grupo.

A primeira questão é que das duas pessoas com as quais eu tive relações amorosas nesse período, nenhuma delas valorizava esse projeto e, de certa forma, até obstacularizavam algumas ações que eu queria fazer com o coletivo.

Além disso, eu estava no período da pós-graduação, e as atividades da mesma faziam com que eu me ausentasse longos períodos de Porto Alegre, então eu mantinha uma relação centralizada com o "Rapaz Tempestuoso", no que para mim era, de dada maneira, um pacto secreto; tínhamos um plano de ação, projetos a serem implementados, pessoas às quais ele estava proporcionando certas experiências, e eu aparecia de vez em quando para viver um pouco daquilo, alimentar e alimentar-me da mística do encontro. Mas também perdi um pouco das etapas do processo, perdi de entender como algumas daquelas pessoas chegaram ao rancho.

Assim, demandado em frentes diversas, nos namoros, na pós-graduação, e nos meus próprios anseios autonomistas, que por vezes distanciavam-se em muito dos anseios do "Rapaz Tempestuoso", eu não me relacionei com profundidade com as pessoas que vinham para o rancho e não compreendi de todo o papel das mulheres em uma série de ações que ali foram realizadas. Posso citar que houveram discussões sobre a divisão das tarefas de limpeza e organização do espaço, sobre o machismo estrutural nas expressões do linguajar cotidiano, sobre a questão das relações livres. Mas tudo isso foi muito centrado caso a caso, conforme as coisas iam acontecendo... $\mathrm{E}$ o rancho teve várias fases, algumas em que só participou uma mulher, outras em que houveram até mais mulheres que homens; em alguns desses momentos o teor de agitação autonomista diminuiu e as pessoas estavam vivendo mais um clima de relação familiar, noutros momentos o clima de comprometimento político foi maior, mas em todos esses momentos, lidar com o ego do "Rapaz Tempestuoso", com a sua "síndrome de liderança" é que era o grande desafio para o grupo, de forma que até as questões de gênero ficavam em segundo plano.

A partir do meu contato com o grupo que se organizou ao redor do 
"Enxaqueca" é que eu comecei a me deparar com mulheres mais atuantes, de iniciativa, propondo e executando os seus próprios projetos. Igualmente, nesse período a discussão a cerca do feminismo começou a ficar mais e mais séria.

Duas dessas mulheres eram italianas, uma chilena, uma mexicana, um pouco de coincidência e muito de contatos circulando na rede, fez com que esse heterodoxo grupo de mulheres estrangeiras acabasse vindo morar em Porto Alegre. Em uma faixa etária mais velha, entre 25 e 30 anos, as preocupações e os acúmulos de vivências e reflexões sobre seus próprios interesses, suas militâncias e a sociedade patriarcal envolvente, fizeram dessas mulheres guerreiras cheias de convicções e estratégias para empoderar-se e lutar contra discriminações e desigualdades.

Elas começaram a experimentar e compartilhar ferramentas de comunicação não-violenta, e formatos de reuniões específicas como encontros e vivências só de mulheres, ou só com as mulheres tendo direito à fala. Passaram a promover também encontros mistos (homens e mulheres) falando sobre: relações interpessoais; amor livre; aborto; maternidade; machismo dentro dos movimentos sociais e grupos políticos à esquerda; e também, numa perspectiva mais mística, abordando o sagrado feminino. Por terem várias origens nacionais distintas, várias socializações específicas, essas mulheres tinham vários entendimentos distintos sobre essas questões, mas estavam irmanadas em um esforço sincero de as entenderem e se entenderem no processo. E igualmente tinham todo um histórico de opressão patriarcal sobre elas; opressão que umas enxergavam de maneira bem consciente e que outras passavam a enxergar naquela experiência de troca.

Entre outros produtos que vicejaram dessas experiências, essas mulheres organizaram dois livros para serem publicados pela Deriva. A tradução de um livro de sobre a experiência de companheiras espanholas em okupas e dentro do movimento social daquele país, "Tesouras para todas" ([2009] 2013); e a compilação de textos clássicos e inéditos sobre a temática do amor livre, "De amor e anarquia: relações libertárias ontem e hoje” (Waslala, org., 2010). O primeiro livro tem sido basilar na discussão de vários grupos que tem tido o interesse de colocar às claras a questão da opressão e violência física e simbólica nas companheiras de movimento; o livro ganhou outras versões e está disponibilizado gratuitamente na internet. $\mathrm{O}$ segundo livro foi fruto da reflexão inerente às "relações livres" que aconteceram nessa rede, aos sucessos e insucessos, estreitamento de laços sexuais/amorosos e/ou os seus rompimentos no correr dessas relações. 
$\mathrm{O}$ assunto é espinhoso e deve ser tratado com responsabilidade. Ainda não tenho condições para abordá-lo com o distanciamento e a reflexão necessários. $\mathrm{O}$ que posso argumentar nesse momento é que o empenho para repensar as maneiras como estão organizados os nossos relacionamentos (o teor; as narrativas fundantes; as estruturas de dominação e controles psicológicos e corpóreos; os equacionamentos com outras esferas da vida, da econômica à política; a desigualdade tácita entre direitos e deveres, sobretudo dos homens) é super válido, muito bem-vindo.

Contudo, a busca incessante por liberdade sexual e afetiva, que tem sido a "pedra de toque" do comportamento de muitas pessoas envolvidas com essas práticas e reflexões, traz como contrapartida perspectivas individualistas claramente egocêntricas e hedonistas, que muitas vez beiram a alienação e o descompromisso com a saúde física e psicológica dos envolvidos. Geralmente o que temos é um indivíduo buscando a satisfação de seus desejos de maneira casual (e por vezes caótica) sem se preocupar com os sentimentos, saúde ou necessidades seja do seu parceiro fixo, seja dos seus parceiros esporádicos.

Claro que os desejos e necessidades individuais devem ser respeitados, potencializados, e que também a forma como vem sendo institucionalizados os gêneros e suas particularidades, as relações sexuais, matrimoniais e familiares, configuram verdadeiras prisões aos desejos e conformam um sem número de valores e práticas hipócritas, opressivos e patogênicos. Mas se uma série de estruturas sociais e psicológicas presentes em nossa socialização vinculam relações amorosas/sexuais com prioridade de afeto, de tempo, com solidariedade produtiva, a quebra desses paradigmas deve ser um esforço plural e não individual e deve ser experimentado com cuidado e respeito pelas pessoas envolvidas, caso contrário corre o risco de cair no imediatismo consumista, na alienação e tantos outros males que os libertários criticam na organização social atual.

Igualmente, outra crítica que podemos traçar sobre a polêmica do "amor livre", é que, embora muitas mulheres estejam conseguindo vivenciar essas experiências, a grande maioria dos casos é desejado ou facilitado para os homens que querem ter mais de uma parceira sexual, mas não querem ter $o$ comprometimento afetivo e também obstacularizam quando as mulheres com as quais se relacionam querem vivenciar a mesma liberdade.

A perspectiva dessas mulheres, do tempo, do espaço, as práticas que elas precisaram e desenvolveram para empoderar-se foi fundamental para todos crescermos como pessoas e refletirmos sobre os nossos posicionamentos. Mas 
onde está o machismo? Onde está o peso do patriarcado? Onde o medo é paranóia? Onde os inocentes pagam pelos culpados, pela estrutura viciada? Onde o problema não é sociológico, mas psicológico e determinadas relações são destinadas ao sadismo, independentemente das ideologias propaladas no ambiente? Essas são perguntas que sistematicamente eu tenho me feito quando me enfrento com as questões de gênero, das opressões reais da sociedade patriarcal e com as políticas de determinadas vertentes do feminismo.

Sei que fui muito machista, violento e perverso em vários relacionamentos, mas também fui vítima de abusos (gratuitos?) por parte de mulheres com as quais me relacionei. Sei que o problema, como o problema racial, nunca é individual, sempre é coletivo e estatístico, mas e quando as nossas certezas viram premissas para julgar e culpabilizar os inocentes? Escrevo isso porque é bom que as mulheres se empoderem, que a discussão feminista transforme certas práticas pavorosas que existem entre os homens, ou que beneficiem os homens... mas também já vi alguns enganos, alguns inocentes sendo escrachados, achincalhados e exilados sem provas legítimas e muito tempo depois o engano sendo revelado. Mas estatisticamente e estruturalmente isso é menor e menos importante do que o que as mulheres sempre sofreram, sempre sofrem... Sim e não, não sei se compensa, não sei se uma coisa justifica ou relativiza a outra.

\section{Cena etnográfica 3: grupo de discussão feminista, durante a $5^{\text {a }}$ Feira do Livro Anarquista de Porto Alegre, dezembro de 2014}

Estava nesse espaço para divulgar o livro "As Rebeliões da Tarifa e as Jornadas de Junho no Brasil", organizado por mim e por Cassio Brancaleone (2014), por uma série de fatores, levei o meu filho junto, na época com 5 anos. Estávamos em uma praça e terminada a minha atividade, ficamos por ali, ora passeando entre as bancas, ora brincando nos brinquedos da pracinha infantil. Eu queria ver as discussões, então deixei o meu filho mais a vontade, correndo pelo espaço atrás de outras crianças, mas de longe o acompanhava com os olhos. Num determinado momento, ele estava brincando desacompanhado e eu fui me aproximando, justamente para o proteger de estranhos, quando sou abordado por um casal de meninas que estava responsável por uma outra criança que também brincava perto:

- Ei, tu és o pai do menino? - disseram elas, em uma postura defensiva, prontas para bloquear o meu avanço, se fosse necessário.

- Sim, sou! - respondi e pedi a confirmação dele, que prontamente atendeu. E elas sorriram gentilmente e me deixaram passar. 
Um pouco depois começou uma roda de conversa de mulheres. Eu conhecia algumas das presentes e fui me aproximando. Tinham mulheres transexuais, tinham outros homens cis, então eu não me senti constrangido em me aproximar para ouvir a discussão. Desde o princípio as regras foram estabelecidas por uma das mediadoras:

- Essa é uma discussão das mulheres, não é permitido aos homens se manifestarem, podem ouvir, mas não podem falar, se pudéssemos até faríamos essa discussão em um espaço reservado, mas não tem como.

Houve alguns comentários se a mulher trans poderia ou não participar, a maioria das presentes endossou sua participação, então tudo bem. Mas num determinado ponto da conversa, um "desconstruidão", cabeludo, barbudo, de saia, que tinha chegado no meio da pauta, começou a querer falar (nem me lembro sobre o que). As mulheres estavam tentando ser condescendentes, mas o sujeito não se dava por conta. Enquanto isso, eu estava pela periferia da roda e o meu filho viu uma amiga nossa e quis ir ficar perto dela, que estava sentada na parte mais interna da roda; eu não queria me meter, nem atrapalhar a discussão, mas tive que chegar mais perto, pois o menino estava demandando um pouco de atenção, querendo brincar, falando um pouco alto. Nesse ínterim, a arrogância do "desconstruidão" chegou a tal ponto que algumas mulheres perderam a paciência e lhe explicaram a situação:

- Velho, fica na tua, essa é uma roda de conversa pras minas sacou? Tu já tem bastante espaço pra ficar dando as tuas opiniões por aí, agora é a nossa vez!

- Mas... - o cara ainda tentou continuar.

- Mas, nada... Chega, fica quieto, respeita a minas! Fica quieto, fica quieto!

E aí uma mulher, que, imagino não estava muito contente também com a minha presença, perambulando por ali com o meu filho, emendou:

“- Guri abusado [falando do desconstruidão], depois fica que nem o outro [eu, no caso]: homi criando homizinho (sic)."

Eu entendi o recado, peguei meu filho pela mão e fui curtir os outros espaços da feira. Ele ainda tentou argumentar que queria ficar com a nossa amiga e eu lhe disse que esperasse, que ela estava numa atividade importante, só para as mulheres, que depois ele falava com ela.

Pensando sobre essa cena vejo duas disposições para a interação social, presentes tanto na postura de homens quanto de mulheres: o cuidado e a intransigência. As meninas que perguntaram se eu era o pai do menino que viram brincando sozinho, estavam sendo cuidadosas; as mediadoras explicando as regras daquela conversação também; a minha amiga, querendo brincar e dar colo para o meu filho também. O rapaz falador e a moça que colocou a mim e ao meu filho na "mesma barca" que ele estavam sendo intransigentes. Ele por 
falar demais, não saber escutar e querer aparecer sem ser cuidadoso com aquilo que as mulheres já tinham acordado... e ela por generalizar, sobretudo por tachar um menino de 5 anos de "homizinho" no tom mais pejorativo possível, sentenciando que o futuro dele é o de reproduzir o machismo sempre pelo simples fato de ter nascido homem. Penso que esse nível de determinismo é equivocado e desalentador quanto a própria eficácia do feminismo, caso as mentalidades já estejam dadas e nada possa ser reformulado, nem nas relações intergeracionais.

Entre essas duas disposições, politicamente quero me alinhar com a busca do cuidado e por conta disso que não vou expor mais. Não sou mulher, meu lugar de fala é outro, tenho interesse pelas reflexões teóricas e pelas pautas políticas feministas e não estou aqui para argumentar o que é certo ou errado sobre esse tema, mas sei que posturas que me afastam e quais me acolhem, com quem eu consigo conversar, aprender e militar e com quem eu não consigo.

Comentei sobre o feminismo porque é uma pauta cada dia mais presente nas reflexões e práticas que querem abrir o mundo, para que, como dizem os zapatistas, "haja um mundo onde caibam vários mundos". Mas cogitando sobre isso, vejo que a minha rede anarquista é bastante masculina porque eu sou homem e, aceitemos ou não, ainda é muito marcada, muito dividida, a sociabilidade de homens e mulheres em muitos dos pontos de contato das nossas redes. O machismo e a inércia das categorias patriarcais estão aí e temos que ser cada vez mais vigilantes para erradicar essas práticas, e nisso a autocrítica e a disposição para o diálogo e a mudança são extremamente necessárias.

\section{O INVERNO (NUCLEAR) DOS SONHOS E A PRIMAVERA DO QUE É POSSÍVEL}

Em 2011 aconteceram duas coisas importantes: eu assumi meu cargo como professor da Universidade Federal da Fronteira Sul - Campus Erechim e houve o acidente nuclear de Fukushima. Os dois acontecimentos não têm a menor ligação de causa, mas geraram efeitos indeléveis na minha sociabilidade libertária.

Por conta da minha nomeação, eu me vi espacialmente distante da rede e do cotidiano de agitação libertária e autonomista de Porto Alegre e cercanias. O que não foi de todo ruim porque a Região Norte do RS é como um cadinho cheio de questões sociais interessantes. É um dos berços do MST (Movimento 
dos Trabalhadores Rurais Sem Terra) e do MAB (Movimento dos Atingidos por Barragens). Tem concentração de população indígena em um nível estatístico quase amazônico; Erechim, por exemplo está no meio do território ancestral Kaingang, e aqui também tem presença de grupos Guaranis. Comunidades quilombolas também lutam por reconhecimento na região. Há um movimento sindical de certo relevo e toda uma história de fábricas ocupadas e geridas pelos antigos funcionários e de cooperativas fortes e engajadas socialmente. Através de textos de Edgar Rodrigues (1987) e Maurício Tragtenberg (1991), temos notícias de que no início do século XX, nas ondas migratórias vindas do Leste Europeu, estabeleceram-se na região de Erebango e Erechim alguns trabalhadores russos de formação comunista e anarquista que aqui fundaram federações e, possivelmente, até uma experiência de comuna, infelizmente tem sido difícil a busca dos rastros, registros e da influência causada por essas experiências durante as décadas posteriores (SOUZA; OLIVEIRA, 2010).

Desde de a minha chegada na região, tenho tido a sorte de encontrar algumas pessoas politicamente "arejadas", sejam simpatizantes ou pessoas autoidentificadas enquanto anarquistas, libertários ou autonomistas. A maioria destas não é natural dessa região e teve um contato bastante errático com essa perspectiva política, mais pela divulgação dessas ideias na cultura musical punk e pela leitura de livros ou material internético e, portanto, poucos tiveram um contato direto com militantes anarquistas.

A relação mais profunda e profícua que desenvolvi foi com Cassio Brancaleone, sociólogo andante, estudioso do Movimento Zapatista, dos anticapitalismos e das sociabilidades emergentes. Inclusive, a partir do seu incentivo e persistência, temos agremiado pesquisadores e desenvolvido pesquisas através do GPASE (Grupo de Pesquisas Anticapitalismos e Sociabilidades Emergentes), vinculado ao CNPQ e parceiro do grupo homônimo do CLACSO. Por meio desse grupo temos construído uma agenda de pesquisa sobre os temas e grupos sociais identificados acima, buscando unir a reflexão acadêmica e a militância engajada na construção de interpretações científicas e solidariedade política.

Contudo as especificidades demográficas, políticas e culturais da região fazem dela um reduto de caudilhos políticos, tanto a esquerda quanto à direita, com rebanhos eleitorais bem definidos e sobre os quais pesam aparelhos ideológicos que conformam uma mentalidade conservadora, xenófoba, separatista, racista, machista e subserviente. Não se pode generalizar esse quadro, mas ele é representativo de muitos dos esquemas simbólicos e sociais 
aqui existentes. De forma que, a terra não tem sido muito fértil para a propaganda anarquista, existindo uma desconfiança e uma resistência muito forte a simples presença de pessoas que assim se identificam, ao contrário de cidades maiores onde até se é mal visto, mas se é tolerado como parte da paisagem de coletivos e entidades políticas; aqui não, aqui parecemos alienígenas que devem ser extirpados para não comprometer a coesão social. Mas seguimos e temos conseguido incomodar alguns poderes estabelecidos e propor o alargamento do horizonte democrático entre os grupos que participamos e/ou mantemos solidariedade. Justamente o almejar essa inserção social para propagandear pela ação a perspectiva anarquista é que levou um restrito número de anarquistas nessa região a buscarem a integração com uma frente anarquista mais organizada e com um programa mais efetivo. Logo mais volto à considerações sobre isso.

Fukushima. Sabemos que por conta de um tsunami, houve o derretimento de reatores e o vazamento de material radioativo de uma central nuclear em Fukushima, em março de 2011. Sabemos que em 2013 a empresa responsável pelo empreendimento e o governo japonês estavam tendo dificuldades para conter e administrar a contaminação de águas oceânicas por material radioativo que continuava a vazar dos reatores. Leio uma notícia do Diário de Notícias português de fevereiro de 2017 , dizendo que a radiação na zona central atingiu valores recordes, dezenas de vezes maiores do que na última verificação e que o trabalho de desmonte da usina deverá durar 4 décadas $^{7}$.

$\mathrm{Na}$ atual conjuntura informacional, em que estamos saturados de estímulos e informações, controversas e desencontradas, onde a ficção é realista e a verdade é surreal, onde já foi declarado o fim da história e a legitimidade da pós-verdade, como sabemos qual é o real impacto da crise ambiental que se expande? Qual é a urgência da nossa vigilância, das tentativas de contornar os efeitos nocivos do estilo de vida urbano-industrial?

Durante 2011, "Enxaqueca" ficou obcecado com Fukushima: qual o real impacto? Os efeitos a longo prazo e em máxima dispersão? O que estava sendo ocultado e negligenciado? Ele não dormia, se alimentava mal, varava dias pesquisando na web, na deep web, em sites sérios, em sites duvidosos, criando as suas próprias teorias. Ele deixou de se preocupar com os projetos e ações que estávamos encaminhando, argumentava que nada disso importava se em pouco anos a poluição nuclear inviabilizaria qualquer uma de nossas ações.

7 Notícia disponível em: http://www.dn.pt/mundo/interior/radiacao-recorde-em-central-defukushima-pode-matar-em-uma-hora-5647007.html. Acesso em 02 de junho de 2017. 
Como uma Cassandra moderna, ele passou a lançar suas profecias apocalípticas sem que ninguém pudesse acreditar nelas. Sua então namorada não podia, adepta de uma organização anarquista especifista tinha que denunciar a política social e econômica dos governos das elites e tentar, como minoria ativa, trabalhar para fomentar a organização e o poder popular; isso é o que era urgente e necessário para ela. Eu não podia pois tinha um filho pequeno para criar, uma tese de doutorado para terminar e um emprego público que não podia abandonar. Outros amigos não podiam acreditar em suas revelações por razões semelhantes. E então "Enxaqueca" que estava dando muita dor de cabeça a todos, entrou em um auto-exílio, um período sabático, que até onde eu saiba, ainda não terminou.

Antes de sumir, fiquei sabendo que procurava cavernas amplas e profundas, onde talvez pudesse instalar bunkers e tentar estabelecer uma meiavida. Impactado por suas visões, conversei com uma amiga, também mãe de uma criança pequena, lhe perguntando se, no caso de isso ser verdade, ela fugiria pra esse bunker. Ela me olhou seriamente e uma lágrima rolou de seu olho, ela disse que mataria seu filho e se mataria, que não viveria indefinidamente na escuridão.

Como eu argumentava, no meio de tantas versões, de tanta informação e de tanta fragmentação do conhecimento, da inércia, da rotina e de tantos afazeres dentro da máquina produtiva do capitalismo moderno, de tantas outras urgências da política e do desejo, não tive como investigar por mim mesmo o que virá desde Fukushima. O ponto é que em algum ponto é legítima e verdadeira a preocupação de "Enxaqueca", sua urgência em pensar os efeitos da degradação ecológica são importantíssimos e perante esse cenário a política militar ou econômica dos Estados-Nação para daqui poucos anos chega a ser irrelevante. E se enquanto nos preocupamos com superficialidades, o destino da espécie humana e do próprio planeta estão assinalados para antes do fim do século?

Mas não tivemos como incluir essa preocupação em nossas agendas, por sermos poucos, pequenos, escravos do sistema e de suas obrigações, escravos da realpolitik moldada desde os agentes centrais, que têm pouca consideração pelas pautas ambientais. "Enxaqueca" foi para o seu ostracismo e levou consigo muito da energia que movia as iniciativas que circulavam na rede em que ele era um ponto constelador. "O Rapaz Tempestuoso" era muito sonhador, "Traça” muito niilista e pragmático, "Bit" menos iniciador e eu muito refém das obrigações sistêmicas. De forma que as coisas minguaram. 
Um jeito de me pacificar e mobilizar as minhas energias para alguma ação efetiva foi me dedicar aquilo que estava acontecendo em Erechim. Como expliquei acima, temos o GPASE e por meio dele conseguimos nos agremiar com outros coletivos no intuito de realizar encontros como o $1^{\circ}$ Colóquio Anarquismo e Lutas Sociais (2011) e o Encontro dos De Baixo Erechim (2014); organizamos grupos de estudo e outras atividades mais pontuais. No decorrer dos eventos, estabelecendo pontes com outros ativistas e coletivos, e, dos processos reflexivos, entendendo que isolados na dinâmica local não alcançaríamos uma prática militante efetiva... concluímos que deveríamos inserir-nos em uma frente de anarquismo social que nos desse um prumo organizativo e nos conecta-se com uma agenda de denúncias, reivindicações e lutas mais ampla, regional, nacional e internacional.

Por isso é que Cassio, eu e mais dois militantes de Erechim, "Lunetas" e "Dreads", entramos para a "FAO" ("Frente Anarquia e Organização") a partir de 2014, buscando acertar o pé dentro do especifismo. Essa perspectiva de organização vem da experiência histórica Sul-Americana de inserção anarquista em Movimentos Sociais mais amplos e entende que através de ferramentas políticas - de democracia interna, ação coletiva disciplinada, inserção social (coerente com os princípios e acordos do coletivo anarquista) dentro de determinado espaço geográfico ou movimento social - podemos ampliar a organização e a perspectiva anarquista aonde vivemos e trabalhamos. Não ser vanguarda de nada, mas problematizar, desde nossas concepções, os problemas e soluções postas e disputar os métodos de enfrentar essas situações e quais as escolhas a serem implementadas, na busca de uma coerência programática entre o ideal e a práxis. Inclusive, também é muito relevante o protagonismo feminino na estrutura da FAO.

$\mathrm{Na}$ verdade esse processo de militância organizada não tem sido fácil. A demanda, as burocracias, a afinação ao perfil militante, tem sido extenuantes e muitas vezes ficamos aquém do esperado ou do desejado. Outras vezes me pergunto se os problemas sociais que debatemos, denunciamos e nos preocupamos são os problemas que deveriam estar na nossa agenda. As crises de governo são cíclicas, não me importa tanto quem está lá, me importa é como sair desse jugo e de alguma forma demonstrar para outras pessoas que isso é possível.

De alguma maneira, desde os meus "anos de formação" (ver seção 1), o exemplo da FAO está ali, sempre coerente, sempre militante. Em outros momentos quase me acerquei mais efetivamente dela, mas havia o meu "ranço" 
com a organização, com a disciplina. Aconteceu de eu necessitar estar mais organizado e perceber que nos grupos mais espontâneos eu estava sujeito a devaneios com pouco aderência ao real, ou a microtiranos cheios de paixões e vontades sujeitas à oscilações imprevistas. Na FAO, por outro lado, está instaurado o reino da necessidade: a necessidade da burocracia; a necessidade de se estar pautado pela realpolitik dos de cima (não para tudo, mas para muitas coisas); a necessidade de se estar de acordo com a maioria (embora haja dispositivos de registro documental de posições minoritária) e a necessidade de se abandonar a ética/estética desejante e devaneante do anarquismo ontológico.

As oposições e contradições estão aí, permitam-me ilustrar a polêmica com três cenas etnográficas.

\section{Cena etnográfica 4: Conversa com bioconstrutor na ecovila Lago Verde, setembro de 2013}

Por conta por intermédio de uma das italianas, amigas de "Enxaqueca", fiquei sabendo do trabalho da ecovila Lago Verde e me inscrevi para fazer um curso de bioconstrução lá. O facilitador era um homem chamado Lauro, um dos idealizadores da ecovila. Estávamos terminando uma parede de adobe e conversando. Em determinado momento ele me perguntou se eu era anarquista, mediante a minha resposta afirmativa ele replicou:

- Eu sou libertário, autonomista! Tu conheces a FAO? O que que tu achas dela? [eu respondi que conhecia, que estava "namorando" a possibilidade de me inserir nela e ele sorriu, mexeu a cabeça e continuou...] Um tempo atrás, entramos em contato, mas a coisa não foi adiante... muito Bakunin, Proudhon e tal... muito certinha. Eu não sou assim, eu li só o Hakim Bey, o TAZ (2010), mas é assim que eu sou e vou te dizer, acho que faço mais pela anarquia como eu sou, com o que eu faço aqui, do que com esse monte de teoria, com essa postura de partido.

\section{Cena etnográfica 5: reunião intensiva da FAO, abril de 2016}

Uma reunião intensiva, um fim de semana todo para estudos, análises de conjuntura, atualização programática. Por conta do meu passado "anarcotropicalista" e do meu gosto por Hakim Bey, eu estava sofrendo algumas provocações jocosas, mas tudo bem. A coisa ganhou outra relevância quando, Samara, uma militante veterana defendeu que tínhamos que fazer uma campanha internacional de solidariedade para a compra ou a construção da sede própria da organização e eu coloquei que muitas pessoas poderiam querer ajudar, mas na falta de dinheiro poderiam doar tempo de trabalho e que inclusive poderia se 
utilizar métodos de bioconstrução na edificação. Samara revirou os olhos e lançou um sorriso irônico e soltou o verbo:

- Já estou até imaginando... Qual o nome daquilo, mesmo... Um Earthship, todo de adobe, decorado com as cores da Jamaica, ou algo bem hippie, e no salão principal um mega pôster do Hakim Bey.

Eu já estava meio por conta das piadinhas e respondi na hora:

- Claro Samara, é bem melhor a gente continuar financiando a indústria do cimento, na qual vários irmãos trabalham até empedrar os pulmões em um ambiente totalmente insalubre. Não estou só sendo "bicho-grilo", estou pensando noutro paradigma de consumo e produção, se o Hakim Bey me ajudou nisso, não vejo problema nenhum.

\section{Cena etnográfica 6: conversa com "Enxaqueca", Porto Alegre, janeiro de} 2014

Ele tinha voltado de uma de suas viagens exploratórias, atrás de cavernas, mas já não falava tanto no assunto, pois sabia do desconforto que gerava na gente. Ele desistira do investimento em uma comuna rural que planejáramos durante anos e estava irredutível nisso... No meio da conversa, lhe comentei que estava seriamente inclinado a me vincular à $\mathrm{FAO}$ e ele disse:

- Eu acho bem bom tu te vinculares a FAO, aproveita e abre os olhos deles, eles são míopes, não sabem fazer análise de conjuntura, só sabem falar desde a política eleitoral institucionalizada, da macroeconomia, não têm uma perspectiva ambiental. Falam e falam de ações de médio e longo prazo e não querem nem pensar na crise ecológica que está por vir.

Eu poderia descrever outros eventos, outras cenas etnográficas que ilustram o teor das polêmicas, mas penso que "já deu pra sentir o drama". E talvez esse drama seja um dos cernes das políticas internas à identificação anarquista entre indivíduos e coletivos. Entre tantos outros Bookchin ([1972] 1999; 2012) e Bey (2008) debruçam-se sobre essa questão que pode estar resolvida antropologicamente, pois uma mesma identidade coletiva tem entradas individuais plurais e está tudo bem enquanto certos sinais adscritivos, ou diacríticos (que são os elementos constituintes de identidades coletivas), 
forem entendidos e respeitados por indivíduos de ambos os lados. Na rede anarquista esses sinais são a recusa de práticas ou instituições como o Estado, o trabalho alienado (sim, anarcocapitalistas ou libertarianos não são anarquistas), a autoridade formal, a dominação de corpos e mentes.

Tanto anarquistas sociais quanto individualistas evocam um projeto (um destino comum) de autonomia, e liberdade para todos os indivíduos, mesmo que divirjam nas táticas para a sua efetivação; compartilham de vários métodos e princípios éticos, se conseguem de fato viver o dito e dizer o feito é outra questão; celebram uma origem ou uma estrutura em comum, atestando que a anarquia sempre existiu no apoio mútuo enquanto solidariedade espontânea e mesmo nas mais diversas sociedades (KROPOTKIN, [1902] 2012; BEY, 2010; GRAEBER, 2011) em tempo indefinido, e como experiências de pico, de curta duração, mas muita intensidade, na Comuna de Paris, na Makhnovitchina, na Espanha Revolucionária etc. (BEY 2010; GRAEBER, 2011)... Tantas similaridades que se definem como projeto político podem ser lidas a luz do idioma da etnicidade e existem vários casos de grupos étnicos que se fundam ao redor de projetos políticos, por exemplo, os Tsimihety de Madagascar, os quais Graeber aborda como lição de etnogênesis (2011).

Assim, vendo antropologicamente, as rusgas entre anarquistas sociais e individualistas são tensões aceitáveis dentro dessa identificação mais ampla, assim como os sotaques de uma língua ou os regionalismos dentro de uma nacionalidade (e peço que os mais sensíveis perdoem as metáforas centralistas).

Se externamente, e modelarmente, a questão está pacificada ${ }^{8}$, nos acontecimentos, nas narrativas, nas tomadas de ações e nos pactos para as mesmas, a desconfiança e o rancor, a descrença no outro e a crença na superioridade do seu modelo permanecem. As disputas egóicas, pela razão, pela glória, pelo valor, pela "verdade verdadeira", pelo projeto definitivo ou a deserção desse, sobrexistem.

\section{CONCLUSÕES?}

Sem necessariamente concluir, abandono essa escritura, não que não tenha mais nada para ser dito, não é isso... é que ainda deve se dar mais tempo para certas

8 Os desviantes, os desertores (anarcos que viram marxistas, misticistas e mistificadores, ou pior, yuppie ou fascistas), os embusteiros (como um anarcotropicalista da UFRGS disse para se "aparecer" para uma menina: “Aqui todos são anarquistas e eu sou o chefe deles!”), todos esses tipos são aceitos como pontos matriciais possíveis. Mas na prática é emocionalmente duro ver esses padrões se criarem dentro do campo libertário. 
possibilidades virarem certezas e certas certezas soçobrarem.

Nesse texto busquei descrever de maneira mais objetiva e analítica alguns eventos e interpretações da minha experiência, trajetória, anarquista, não pela importância da minha experiência por si, mas como uma experiência nativa, que embora particular se alinha à construções e condicionantes que influem sobre um grupo mais amplo. Nesse caso específico, a experiência geracional de estudantes universitários com tendências libertárias na Porto Alegre do começo do século XXI.

Essa foi uma descrição inicial, com objetivos bem modestos, entre eles o de compilar um pouco do espírito de uma época e como que dele se padronizou um caminho de ação política, de participação social. Outras leituras, outras amarrações teóricas precisam ser trazidas ao debate para melhor compreendermos esse processo, o nosso processo, que leva à dissidência, à resistência, à anarquia, e o que a freia.

Entendo ser necessário que aqueles pesquisadores vinculados às humanidades que se identifiquem com essa temática, que a busquem, não só em seus projetos acadêmicos, mas em seus projetos políticos e de vida, realizem o esforço de descreverem e analisarem as suas entradas, iniciações e as formas em que se mantém nessa rede, nesses cenários de sanha libertária e autonomista, nestes coletivos anarquistas.

Precisamos de mitologia, precisamos de história, precisamos de teoria anarquista, mas precisamos de tudo isso, também desde lugares mais próximos, mais comuns. Já temos os nossos autores clássicos, já temos aqueles eventos e experiências sociais de referência incontesta, mas precisamos refletir também sobre as ações mais próximas, menos purificadas, mais indigestas, rotineiras, apaixonantes ou negligenciadas. Precisamos entender a anarquia possível (para talvez compreender porque que ela ainda não é do tamanho dos nossos sonhos), precisamos compilar e validar seus efeitos anarquizantes (Bey, 2008) e compreender e minar seus efeitos autoritários.

Essa reflexividade talvez nos ajude a sermos mais coerentes com nossos desejos, discursos e práticas; talvez nos ajude superarmos nossas tendências isolacionistas e puristas, dentro do próprio movimento anarquista, quanto em relação a sociedade envolvente.

Somos o que somos. Se o Estado e o Capital nos oprimem, nos obrigam à digna rebeldia, saibamos nos entender, saibamos nos construir, saibamos compreender o que nos une em solidariedade com outras pessoas na luta pela liberdade e autonomia, naquilo que pra mim foi definido nessa máxima da 
sabedoria judaica, atribuída ao rabino Hilel: "Se eu não for por mim, quem o será? Mas se eu for só por mim, que serei eu? Se não agora, quando?”.

\section{REFERÊNCIAS}

BARTHES, Roland. Aula: aula inaugural da cadeira de semiologia literária do Colégio de França, pronunciada dia 7 de janeiro de 1977. 13. ed. São Paulo: Cultrix, 2006. 95 p.

BEY, Hakim. Sobre a Anarquia. In: Guerra da Informação e outros textos. Proto Alegre, RS: Deriva, 2008.

BEY, Hakim. Zonas Autônomas Temporárias. Porto Alegre, RS: Deriva, 2010.

BOOKCHIN, Murray. Espontaneidade e Organização. In: Municipalismo Libertário (seleção de textos) São Paulo, SP: Editora Imaginário, 1999.

BOOKCHIN, Murray. Anarquismo social o anarquismo personal: un abismo insuperable. Barcelona, Espanha: Vírus Editorial, 2012. 101p.

BRANCALEONE, Cassio; BEM, Daniel de (ORGS.). As rebeliões da tarifa e as jornadas de junho no Brasil. Porto Alegre, RS: Deriva, 2014. 158 p.

DELEUZE, Gilles; GUATARI, Felix. Mil platôs: capitalismo e esquizofrenia. Rio de Janeiro : Ed. 34, 1995-1997. 5 v.

GALEANO, Eduardo. O Livro dos Abraços. Porto Alegre: L\&pm, 2005. 271p.

GODBOUT, J.T. Introdução à dádiva. Rev. bras. Ci. Soc., São Paulo, v. 13, n. 38, p. 39-52, Oct. 1998 . Disponível em: <http://www.scielo.br/scielo.php? script=sci_arttext\&pid=S0102-69091998000300002\&lng=en\&nrm $=\mathrm{iso}>$.

Acesso em 29 de junho de 2017

GRAEBER, David. Fragmentos de uma antropologia anarquista. Porto Alegre, RS: Deriva, 2011. 186 p.

KROPOTKIN, Piotr. Apoio mútuo: um fator de evolução. São Sebastião, SP: A Senhora, [1902] 2012. 230 p.

LENGEN, Johan van. Manual do Arquiteto Descalço. São Paulo: B4 Editores, 2014. 707 p.

RODRIGUES, Edgar. A comunidade livre de Erebango (Imigrantes libertários 
russos no sul do Brasil). In: PRADO, Antonio Arnoni (org). Libertários no Brasil: Memória, Lutas, Cultura. Editora Brasiliense, São Paulo: 1987.

SAHLINS, Marshall. A sociedade Afluente Original. In: Cultura na prática. Rio de Janeiro: Ed. UFRJ, [1972] 2004, p. 105-151.

SOUZA, Fábio F. Feltrin de; OLIVEIRA, V. Memórias em disputa: uma reflexão sobre a colônia anarquista de Erebango. In: I Seminário Regional e Fórum de Educação no Campo, 2013, Santa Maria. Anais do I Seminário Regional de Educação no campo, 2013. v. 11. p. 1-10.

TESOURAS PARA TODAS. Textos sobre violência machista nos movimentos sociais. Porto Alegre: Editora Subta/Editora Deriva, [2009] 2013.

WASLALA (org.) De Amor e de Anarquia. Porto Alegre: Editora Deriva, 2010. 


\title{
A constellation of anti-capitalist relations in Southern Brazil: Political networks and emergent sociabilities read from an anarchist anthropology
}

\begin{abstract}
This textual effort aims to analyze the sociability of some social actors with whom, and from which, this researcher circulated in a network of people, spaces, discourses and practices identified as libertarian, autonomous, anarchist. The constellation of these social actors: in their patterns; In its advertising and action methodologies, whether in the private or public sphere, in the finalization and purpose of its projections and its projects, was established based on two criteria. Firstly, I have known these social actors, militated with these individuals, collectives and movements, and this becomes a criterion for this analysis. Secondly, I understand that a second fabrication of this network, of this constellation of social actors, is precisely due to a type of data, a type of information that is repeated and is added to the actions and discourses of all these actors, The search for libertarian and autonomous experiences beyond mere identification. The aforementioned constellation of social actors that I will try to reproduce here analytically is temporally from the years 2000 until now and spatially from the state of Rio Grande do Sul.
\end{abstract}

Key-Words: Political Networks. Emerging Sociabilities. Anarchism. 